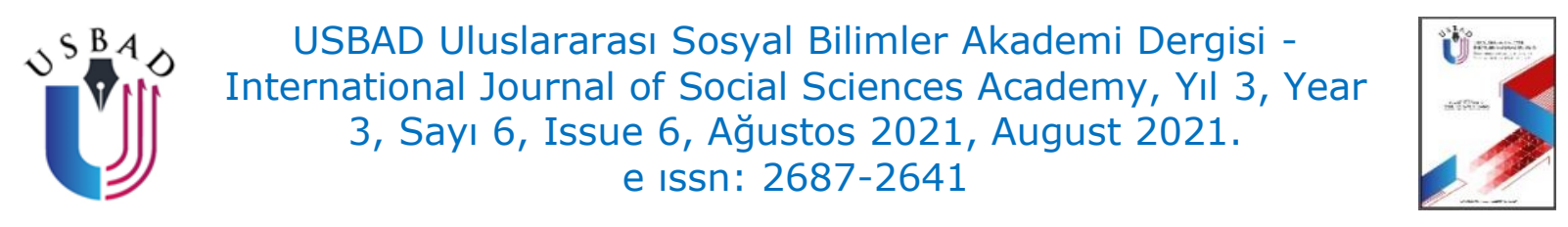

\title{
ERİ̧̧İLEBİLİRLİKTE EŞİK DEĞERLER: İZMİR MERKEZ KENT ÖRNEĞİ
}

THRESHOLDS IN ACCESSIBILITY: IZMIR CENTRAL CITY CASE

\author{
İrem AYHAN SELÇUK \\ Doç. Dr., Dokuz Eylül Üniversitesi, Şehir ve Bölge Planlama Anabilim Dalı, \\ İzmir/Türkiye. \\ Assoc. Prof. Dr., Dokuz Eylul University, Department of City and Regional \\ Planning, \\ Izmir/Turkey. \\ irem.ayhan@deu.edu.tr \\ ORCID ID: 0000-0002-9797-800X
}

Makale bilgisi | Article Information

DOI: $10.47994 /$ usbad. 815845

Makale Türü / Article Type: Araştırma Makalesi / Research Article

Geliş Tarihi / Date Received: 24.10.2020

Kabul Tarihi / Date Accepted: 24.06.2021

Yayın Tarihi / Date Published: 20.08.2021 Yayın Sezonu / Pub Date Season: Ağustos / August

Bu Makaleye Atıf İçin / To Cite This Article: Ayhan Selçuk, İ. (2020). Erişilebilirlikte Eşik Değerler: İzmir Merkez Kent Örneği. USBAD Uluslararası Sosyal Bilimler Akademi Dergisi 3(6), 986-1011.

İntihal: Bu makale intihal.net yazılımınca taranmıştır. İntihal tespit edilmemiştir. Plagiarism: This article has been scanned by intihal.net. No plagiarism detected.

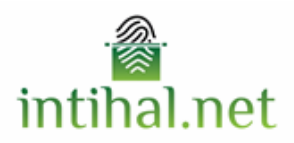

İletişim: Web: https://dergipark.org.tr/tr/pub/usbad mail: usbaddergi@gmail.com 
Öz: Çalışma İzmir Merkez Kentte yer alan otoyol, viyadük ve altgeçitler hariç; toplam 8456 sokaktan; rastlantısal olarak belirlenen 101 sokakta gerçekleştirilen 400 hanehalkı anketini kapsamaktadır. Çalışma kapsamında anket sonuçları değerlendirilmiş ve bireylerin farklı ulaşım taleplerini karşılamak üzere, olası tercihlerini hangi koşullarda değiştirme eğiliminde bulundukları sorgulanmıştır. SPSS programı aracılı̆ıyla gerçekleştirilen tanımlayıcı istatistiklerin değerlendirilmesi, çalışmanın yöntemini oluşturmaktadır. Çalışma sonuçları Coğrafi Bilgi Sistemleri (CBS/GIS) aracılığıyla haritalandırılmış olup; çalışma sonucunda bireylerin alışveriş ve pazar alışkanlıklarında/tercihlerinde, parklanma tercihlerinde, minibüs/dolmuş kullanım tercihlerinde, işe/okula ulaşım tercihlerinde değişikliğe neden olacak eşik değerler İzmir'in merkez ilçeleri kapsamında haritalandırımıştır. Çalışma yerel/merkezi yönetimlerin (1) kent içi ulaşım politikalarının belirlenmesinde ve (2) mekânsal planlar yapım yönetmeliğindeki yürünebilirlik esaslarının tartışıımasında dolayısıyla mekânsal yerseçim kararlarının gözden geçirilmesinde katkı sağlayacaktır. Çalışma Dokuz Eylül Üniversitesi Rektörlüğü Bilimsel Araştırmalar Koordinasyon Birimi tarafından desteklenen 2017.KB.FEN.016 No'lu projenin bir ürünüdür. Aynı zamanda Uluslararası Sosyal Bilimler ve Eğitim Bilimleri Kongresi (USVES) Ekim 2020'de sözlü bildiri olarak sunulmuştur.

Anahtar Kelimeler: Ulaşım, Erişim, Eşik Değerler, Mekansal Kararlar

Abstract: Except for the highways, viaducts and underpasses in İzmir Central City; from a total of 8456 streets; It covers 400 households surveys conducted on 101 streets determined randomly. Within the scope of the study, the results of the survey were evaluated and the conditions under which individuals tend to change their usual preferences in order to meet different transportation demands were questioned. The method of the study is the evaluation of descriptive statistics performed through the SPSS program. The results of the study have been mapped through Geographical Information Systems; As a result of the study, threshold values that will cause changes in individuals' shopping and market habits / preferences, parking preferences, minibus / minibus usage preferences, and transportation to work / school were mapped on the basis of central districts of İzmir. The study is a product of the project numbered 2017.KB.FEN.016 supported by Dokuz Eylül University Rectorate Scientific Research Coordination Unit. At the same time, the International Social Sciences and Educational Sciences Congress (USVES) was presented as an oral presentation in October 2020.

Key Words: Transportation, Accessibility, Thresholds, Spatial Decisions

\section{GİRIŞ}

Ulaşım bizi sadece işe ve ekonomik fırsatlara değil; kaliteli konuta, okula, sağlık bakımına ulaştıran bir role sahiptir. Harvardlı araştırmacılar yolculuk süresinin sosyal hareketlilik çıtasını yükseltmede önemli bir kestirim aracı olduğunu tespit etmişlerdir (Henderson ve Blackwell, 2015). Adil ulaşım politikaları; ekonomik hareketlilikle baş etme şansına sahiptir ve 
toplumdaki herkesin yerel ekonomiye katılımını ve yerel ekonomiden faydalanmasını garanti ederler (Henderson ve Blackwell; 2015).

Literatürde ulaşımın adil dağılımını analiz etmeye yönelik olarak pek çok çalışma bulunmakta olup; ulaşımın adil dağılımı konusunda toplu taşıma sisteminin önemi; sözkonusu çalışmalarla ortaya koyulmaktadır. Bu kapsamda Griffin ve Şener (2016), Martinelli ve Medellin (2007), Teunissen, Sarmiento, Zuidgeest ve Brussel (2015), Nawagawong ve Techapeeraparnich (2017), Cojanua, Dobreb ve Stupariuc (2012), Mortazavi ve Akbarzadeh'ın (2017) ve Guzmana ve Bocarejob'un (2017) çalışmaları incelenmiştir.

Griffin ve Şener (2016), Amerika'nın 9 büyük kenti üzerinden metropoliten ve yerel ölçeklerdeki toplu taşıma eşitlik analizlerini çalışmışlardır. Martinelli ve Medellin (2007) iki metropoliten alandaki otobüs geçiş eşitliğini değerlendirmişlerdir. Teunissen, Sarmiento, Zuidgeest ve Brussel (2015), Bogota'nın sürdürülebilir ulaşıma yönelik girişimleri üzerinden adil erişimi haritalamaya çalışmışlardır. Nawagawong ve Techapeeraparnich (2017) herkes için erişilebilir bir demiryolu istasyonu tasarlanması için sağlanması gereken hizmetlere odaklanmışlardır. Cojanua, Dobreb ve Stupariuc (2012) "Competitive Potential Indeks"'in belirlenmesinde temel Coğrafi Bilgi Sistemleri araçlarından biri olan "Buffer Analizi"'ne odaklanmışlardır. Mortazavi ve Akbarzadeh (2017) ise toplu taşımanın faydalarının dağılımında mekansal eşitliği ölçmeye yönelik bir çerçeve çizmeye çalışmışlardır. Guzmana ve Bocarejob (2017) kentsel form ve mekansal eşitlik üzerine çalışmalarda bulunmuştur.

Griffin ve Şener (2016) Amerika'nın 9 büyük kenti Atlanta, GA; Austin, TX; Dallas, TX; Denver, CO; Houston, TX; Indianapolis, IN; Los Angeles, CA; Seattle, WA; and San Diego, CA'yı çalışırken; Martinelli ve Medellin (2007) Columbus ve Seatlle'l; Teunissen, Sarmiento, Zuidgeest ve Brussel (2015), Bogota'da Columbia'yı; Nawagawong ve Techapeeraparnich (2017) Tayland'da Thai Tren İstasyonunu, Cojanua, Dobreb ve Stupariuc (2012) ise Romanya'da Timisoara, Cluj-Napoca, Brasov, Craiova, Iasi, Ploiesti, Constanta and Bucharest'i çalışma alanı olarak belirlemişlerdir. Guzmana ve Bocarejob (2017) ise Bogota Colombia'yı çalışmışlardır.

Griffin ve Şener (2016) çalışmalarında; toplu taşıma sisteminin göreli eşitliğini değerlendirebilmek amacıyla, toplu taşıma sistemine erişilebilirlik, toplu taşıma sistemine erişimde düşük refah seviyesine sahip çalışanların yüzdesi ve tüm çalışanların toplu taşıma sistemine ulaşımıyla ilgili veri kullandıklarından bahsetmişlerdir. Ramsey ve Bell'den (2014) aktaran Griffin ve Şener (2016); toplu taşıma sistemine erişilebilirliğe referans veren 
ilk değişkenin; "toplu taşıma sistemi ile 45 dakika süren evden işe ulaşım süresine sahip işgücünün; toplam bölgesel işgücü içerisindeki oranı" olduğundan bahsetmişlerdir.

Bununla birlikte Griffin ve Şener (2016) toplu taşıma sistemi bilgisi için, her bir nüfus bloğundan diğerine olan yolculuk süresinin hesaplanması gerektiğini belirtmişlerdir. 2010 yılı nüfus verisini nüfus grupları arasındaki 45 dakikalık yolculuk süresi limitinin aşılıp aşılmadığının belirlenmesi için yapılan hesaplarda kullandıklarını ifade etmiş olup; 45 dakikalık sürenin bekleme süreleri, transfer süreleri ve durağa ya da duraktan yürüme sürelerini de kapsadığını belirtmişlerdir. Ewing ve Cervero'dan (2010) aktaran Griffin ve Şener (2016) yoğunluk değişkeninin, toplu taşıma kullanımındaki farkılışmayı arazi kullanımın bölümlenmesi, sokak tasarımı ve durak noktalarına ortalama uzaklık değişkenleri kadar öngöremediğini ifade etmişlerdir.

Griffin ve Şener (2016) bununla birlikte çalışmalarında; gelecek çalışmalara kent formunun mekansal analizi, konut ödenebilirliği, eşitlikle ilişkili diğer demografik değişkenler ve sosyal hizmetlere toplu taşıma temelli erişimin de eklenmesinin yararlı olacağını belirtmişlerdir. Erişilebilirlik üzerinde çok modlu toplu taşıma yolculuklarının etkisinin ve toplu taşımanın adil olmasının araştırılması gerektiğini ifade eden Griffin ve Şener (2016); toplu taşıma sistemlerinin mevcut ve öneri eşitlik ve hizmet düzeylerinin; eşitlik için kullanılan benzer metotlarla ve mekansal analizlerle modellenmesinin; gelecekteki toplu taşıma hizmetlerinin değerlendirilmesine yardımcı olacağını belirtmişlerdir (Griffin ve Şener; 2016).

Martinelli ve Medellin (2007) çalışmalarında; yaptıkları analizlerin yolcuların otobüs hizmetini kullandıkları sırada karşılaştıkları maliyetleri ve farklı sosyoekonomik yapıya sahip kullanıcılar arasındaki eşitliği incelemeye yönelik olduğunu belirtmişlerdir. Bu da onların ne kadar ödedikleriyle, yolculuk sürelerinin ne kadar olduğu ve geri dönüşte kat ettikleri mesafeyle ilişkilidir. Her kullanıcı ve her hane halkı için toplanan mil başına düşen parasal maliyetler (kullanıcı maliyetleri) ve ulaşım süreleri, farklı demografik gruptan kullanıcılarla karşılaştırılarak yolculuk maliyetleri arasındaki eşitlik belirlenmeye çalışımıştır (Martinelli ve Medellin, 2007). Çünkü kullanıcı bakış açısıyla; toplu taşıma sistemi işletme maliyetlerine, kullanıcı tarafından ödenen vergilere, toplu taşıma şirketleri tarafından alınan sübvansiyonlara (ya da bu subvansiyonların kaynaklarına), otomobilin kullanımı ve parklanmasının optimal olmayan ücretlendirmesine vb. gerekli özen gösterilmemektedir (Martinelli ve Medellin, 2007). Çalışma; aynı zamanda, toplu taşıma hizmetine sahip olma olasılığını; gelir 
dağılımının farklı demografik yapı gruplarından kullanıcılara yeniden dağıtımının bir yolu olarak görmekte olup, bazılarının alternatif ulaşım tercihlerine sahip olup olmadığını da incelemektedir (Martinelli ve Medellin, 2007).

Cojanua vd. (2012) erişilebilirliğin; bir bölgenin ekonomik potansiyelinin sermayelendirilmesinde önemli bir bileşen olduğundan bahsetmiştir. $\mathrm{Bu}$ nedenden ötürü; işçilerin işlerine gitmesinde; hammaddenin dolaşımında ve son ürünlerin endüstriyel alanlardan insanlara akışında; yatırımcılar ve özellikle de Avrupalılar tarafından iş kurmak için dikkate aldıkları elementleri kolaylaştırmaya çalıştıklarını ifade etmişlerdir. Ulaşım altyapısının türü ve yoğunluğu; bölgesel ekonomileri arttırmada iki önemli özelliktir. Böylece, bölgesel bir hinterlandın etki alanı; ulaşım altyapısının yelpazesi ve ulaşım güzergahlarının yoğunluğu kadar büyük (ekspres yollar ve karayollarının) olacaktır (Cojanua vd., 2012).

Mortazavi ve Akbarzadeh (2017) ise çalışmasında Currie'nin (2010) Avusturya Melbourne'de sosyal intiyaçlardan biri olan toplu taşıma arzına temellenen eksiklikleri incelediğinden bahsetmiştir. Currie (2010); arz ve talep için indeksler geliştirmiş; arzın konfor durumunu değerlendirmiş ve Avustralya Melbourne'ün farklı noktalarındaki toplu taşıma ihtiyaçlarını değerlendirmiştir. Arz indeksi; bir bölgedeki istasyon sayısını, her bir Sayfa | 990 istasyondaki servis sıklığını ve bir bölgenin toplam alanı içindeki kapalı alan oranını içermektedir. Talep indeksi ise bir bölgenin farklı özelliklerinden oluşan lineer bir fonksiyondur. Özel araç sahibi olmayan yetişkin sayısı, 60 yaş üstü insan sayısı, öğrenci sayısı vb. Arz ve talebin her biri birbiriyle değerlendirilmiş ve arz ve talep bakımından düşük konforlu bölgeler belirlenmiştir (Currie; 2010'dan akt. Mortavazi ve Akbarzadeh, 2017).

Mortazavi ve Akbarzadeh (2017) Lemans'tan (2015) alıntıladıkları ifadelerinde; Lemans'ın (2015) Netherlands, Utrecht'te adil erişilebilirliği ölçmek için Gini indeksini, Theil indeksini ve tanımlayıcı istatistikleri benimsediğinden bahsetmişlerdir. Değerlendirmede 2015'in güncel değeri ve 2020'nin gelecek değeri dikkate alınmıştır. Araştırmanın dikkat çeken tarafı; Gini indeksinin, Theil indeksi ve tanımlayıcı istatistiklere göre daha iyi çalışıyor olmasıdır. Nedeni; Theil indeks'inde her bir bölgeye erişilebilirliğin; bölgedeki durakların katkısının toplanmasıyla belirlenmesi iken; bir bölgedeki her bir vatandaş için ortalama erişilebilirliği kullanmasıdır. Tanımlayıcı istatistiklerin dezavantajı ise; çalışma alanındaki aykırı değerlerin yüksek hassasiyetidir (Lemans, 2015'ten akt. Mortavazi ve Akbarzadeh, 2017). 
Guzmana ve Bocarejob (2017) çalışmalarında; kentsel alandaki çalışma alanları ve konut alanları arasındaki dengenin çok önemli olduğundan bahsetmişlerdir. Peng'den (1997) alıntıladıkları ifadelerinde; iyi belirlenmiş bir kent yapısında; denge bölgesinin trafik sıkışıklığını ve buna bağlı olarak ortaya çıkan sosyal ve çevresel problemleri hafifletebileceğini belirtmişlerdir (Peng 1997'den aktaran Guzmana ve Bocarejob, 2017). Guzmana ve Bocarejob (2017) Cervero'dan (1995) alıntıladıkları ifadelerinde; bu durumun pek çok eşitsizliği büyük oranda azaltmaya yardımcı olduğundan ve bu dengelemenin kendi kendine yeten alanlarla yakından ilişkili olduğundan bahsetmişlerdir (Cervero; 1995'ten akt. Guzmana ve Bocarejob, 2017).

İşe erişilebilirliği tanımlamanın pek çok yolu vardır. Ancak verilen bir motorize yolculuk süresi içinde ulaşılabilir olan iş sayısı; bölgeler arası doğrudan karşılaştırılabilir en dikkate alınabilir ve açık değişkendir. Bu durumda; "Contour ölçütü" (Geurs, Ritsema van Eck; (2001) ya da "Isochronic ölçüt" (Cervero (2005); 45 dk. maksimum yolculuk süresi olacak şekilde belirlenmiştir. Bu ölçüt erişilebilirlik indeksi olarak tanımlanmıştır: İndeks arttıkça, 45 dakika içinde erişilebilir olan çalışma alanı da artmaktadır (Guzmana ve Bocarejob; 2017).

Ülkemizde ise Türk Dil Kurumu "erişim" kelimesini "belli iki yer arasında Sayfa | 991 gidip gelebilme, ulaşım" olarak tanımlamaktadır (Türk Dil Kurumu Sözlükleri, TDK, 2020). Erişilebilirlik ise 20 Temmuz 2013 tarihli, 28713 sayılı resmi gazetede yayınlanan "Erişilebilirlik İzleme ve Denetleme Yönetmeliği"nde; "Binaların, açık alanların, ulaşım ve bilgilendirme hizmetleri ile bilgi ve iletişim teknolojisinin engelliler tarafından güvenli ve bağımsız olarak ulaşılabilir ve kullanılabilir olmasını" ifade etmektedir. Aynı yönetmeliğin erişilebilirlik standartlarıyla ilgili tanımı; Türk Standartları Enstitüsü'nün erişilebilirlikle ilgili yayınladığı TS 9111, TS 12576, TS 12460, TS ISO 23599, TS 13536, TS 23600 ve diğer standartlara atıfta bulunmaktadır (Aile ve Sosyal Politikalar Bakanlığı, 2013).

Erişilebilirlik tespiti tanımında ise "umuma açık hizmet veren her türlü yapılar ve açık alanlar ile toplu taşıma araçlarının Yönetmeliğin EK-1, EK-2 ve EK-3'ündeki erişilebilirlik izleme ve denetleme formlarında yer alan hususların yerinde ve/veya konu ile ilgili dokümanlar aracılığıla yapılan incelemeler sonucu standartlara uygunluk durumunun belirlenmesi gerektiği belirtilmekte olup; burada umuma açık hizmet veren yapıdan kasıt; kamu hizmeti için kullanılan resmi binalar ile ibadet yerleri, özel eğitim, özel sağlık tesisleri, sinema, tiyatro, opera, müze, kütüphane, konferans salonu gibi kültürel binalar ile gazino, düğün salonu gibi eğlence yapıları, otel, özel yurt, iş hanı, büro, pasaj, çarşı, alışveriş merkezi gibi 
ticari yapılar, spor tesisleri, yüzme havuzu, genel otopark ve buna benzer umuma ait binaları ifade etmektedir (Aile ve Sosyal Politikalar Bakanlığı, 2013).

Ersoy (2009) yaya sistemleri tasarlanırken optimum yürüme mesafesinin $500 \mathrm{~m}$. , tolere edilebilecek en fazla yürüme mesafesinin ise 800-1000 metre olarak kabul edildiğini belirttiği çalışmasında; yaya ağırlıklı erişim sağlanan kullanımlar tasarlanırken bu ölçülerin dikkate alınması gerektiğini ifade etmişlerdir. Bununla birlikte yaya bağlantıları mümkün olduğunca doğrudan ve kısa bağlantılarla gerçekleştirilmelidir (Ersoy, 2009).

Dolayısıyla aslında erişilebilirlik; mekanda yer seçen arazi kullanım türleri ile bu arazi kullanım türlerini birbirine bağlayan ulaşım elemanları/ağları arasında kurulması gereken ve ekonomik, demografik, kültürel ve sosyal ayrım gözetmeksizin mekanın her kesimden kullanıcısına benzer oranda hizmetlere erişim imkanı sunan bir denge unsurunun inşa edilmesidir.

Mekansal Planlar Yapım Yönetmeliği; bu dengeyi yönetmeliğin EK-2 belgesinde yer alan ve yerleşmenin nüfus büyüklüğüne bağlı olarak planlama çalışmaları gerçekleştirilen alana farklı arazi kullanım türlerinden Sayfa | 992 kaç $\mathrm{m}^{2}$ önerilmesi gerektiğini ve her arazi kullanım türünden kişi başına kaç $\mathrm{m}^{2}$ 'lik kullanım alanı ayrılması gerektiğini gösteren detaylı bir tablo ile açıklamakta olup; bununla birlikte 4. Bölüm 12. maddesinde belirtilmiş olan yürüme mesafeleri üzerinden tarif etmektedir. 12. Madde kapsamında; çocuk bahçesi, oyun alanı, açık semt spor alanı, aile sağlık merkezi, kreş, anaokulu ve ilkokul fonksiyonları için yaklaşık 500; ortaokullar için 1000, liseler için 2500 metrelik yaya olarak erişime imkan tanıyacak bir planlama çalışması gerçekleştirilmesi gerektiği ifade edilmiştir. Dini tesisler için ise dini tesisin büyüklüğüne göre 150-250 ve 400 metrelik yürüme mesafeleri içerisinde yer seçim kararı alınabileceği belirtilmektedir. İstisnai durumlarda ise bu mesafeler arttırılabilmektedir (T.C. Cumhurbaşkanlığı Mevzuat Bilgi Sistemi, 2020).

Dolayısıyla; şehir planlama; mekan organizasyonunu yasalar ve yönetmelikler çerçevesinde koruma altına alınan alanları da dikkate alarak bazı standartlar ve yönetmeliklerle belirlenen eşik değerler üzerinden kurmaya çalışan bir yapıya sahiptir. Bu süreçte; plan kademeleri içerisinde yer almayan ancak planlama çalışmalarına veri sağlayan ulaşım ana planı ve diğer planlama çalışmaları arasındaki koordinasyon önem kazanmaktadır. Bu süreçte; ulaşım elemanları ve arazi kullanım türleri arasında kullanıcı temelli eşik değerlerin tespit edilmesi ve elde edilen 
verinin söz konusu planlama çalışmalarında dikkate alınması, planlamanın yapıldığı yerleşmenin koşullarını da göz önünde bulunduran bir yapıya sahip olması açısından önemlidir.

Bu çalışmada "eşik değer" kavramıyla gün içerisinde farklı yolculuk amaçlarıyla yerleşme içerisinde hareketlilikte bulunmak isteyen bireylerin yolculuğa çıkma konusundaki düşüncelerini/eğilimlerini etkileyebilecek maksimum değerleri (maksimum yürüme süresi, maksimum yolculuk süresi, maksimum ödeme yapabilecekleri ücret vb.) ortaya koymak amaçlanmakta olup; çalışma kapsamında anket uygulanan bireylerden alınan yanıtların ilçeler ve mahalleler bazında ortalamaları alınarak dakika ya da TL birimi üzerinden aktarımlar gerçekleştirilmeye çalışıımıştır.

Mekansal Planlar Yapım Yönetmeliği kamusal arazi kullanım türleri için yürünebilirlik üzerinden eşik erişilebilirlik değerleri referans alarak, yönetmelikte dikkat çekilen kamusal hizmet alanlarına erişilebilirlik kıstaslarına benzer şekilde söz konusu değerleri İzmir'de yaşayan bireylerin günlük hayatta gerçekleştirmek zorunda oldukları iş, eğitim, alışveriş amaçlı yolculuklarında ya da söz konusu hareketliliklerini gerçekleştirmede temel araç olan toplu taşıma hattına ya da durak noktasına erişimde ya da özel araçla yaptıkları yolculuk tercihlerini değiştirme etkisine sahip parklanma ücretleri ile toplu taşıma sistemini kullanma yönündeki tercihlerini belirlemede önem taşıyan aktarma yapıyor olma faktörüne yönelik tutumlarını ortaya koymayı amaçlamaktadır.

Bu çalışmanın amacı; mekansal planlama ya da ulaşım sistemlerinin planlanması ya da söz konusu alanlarda politika geliştirilmesinde bir araç olarak kullanılabilecek; kentin kullanıcılarının yer seçim ya da ulaşıma yönelik eğilimlerini değiştirme etkisine sahip eşik erişilebilirlik değerleri konusuna dikkat çekmek ve bu değerleri İzmir merkez kent üzerinden analiz etmektir.

İzmir merkez kenti oluşturan 11 ilçede (kuzey batıdan-güney batıya doğru Çiğli, Karşıyaka, Bayraklı, Bornova, Konak, Buca, Gaziemir, Karabağlar, Balçova, Narlıdere ve Güzelbahçe); rastlantısal olarak belirlenen 101 sokakta gerçekleştirilen 400 hane halkı anketine ait analiz sonuçları çalışmanın kapsamını oluşturmaktadır. Çalışma kapsamında erişilebilirliği etkileyen eşik değerler İzmir merkez kenti üzerinden incelenecektir.

Çalışma Dokuz Eylül Üniversitesi Rektörlüğü Bilimsel Araştırmalar Koordinasyon Birimi tarafından desteklenen 2017.KB.FEN.016 No'lu projenin bir ürünüdür. Aynı zamanda Uluslararası Sosyal Bilimler ve Eğitim Bilimleri Kongresi (USVES) Ekim 2020'de sözlü bildiri olarak sunulmuştur. 


\section{1. ÇALIŞMA METODU}

Çalışmada kullanılan bilimsel yöntemler (1) İzmir merkez kentte yaşayanların yolculuk eğilimlerini ortaya koyması nedeniyle araştırmanın amaçları itibariyle "durum saptayıcı", (2) uygulanan anketlerde örneklem birimlerinin hafta içine denk gelen ve bir gün önceki sabah 6'dan bugün sabah 6'ya kadar olan 24 saatlik seyahat zincirlerini ortaya koyuyor olması nedeniyle kapsadığı zaman itibariyle "kesitsel", (3) uygulanan anket çalışması nedeniyle veri toplama biçimi itibariyle "anket yöntemini kullanan", (4) literatür araştırmaları itibariyle veri toplama biçimi açısından bakıldığında "kitaplık ve internet araştırmalarına" dayanan, (5) İzmir Merkez Kentte gerçekleştirilen anket çalışmalarına dayanıyor olması nedeniyle yapıldığı yer itibariyle "saha araştırmalarına dayanan" bir yönteme sahiptir.

Bununla birlikte çalışma kapsamında toplanan verilerin analiz edilme sürecinde kullanılan SPSS programı ve haritalanmasında kullanılan Coğrafi Bilgi Sistemleri (CBS/GIS) çalışmada kullanılan diğer yöntemlerdir.

Anket süreci gerçekleştirilirken hane halkı ulaşım anketi çalışmalarında esas olan, bireylerin herhangi bir zamandaki değil bir gün önceki yolculuk bilgilerinin alınarak ulaşım talep modelleme sürecinde kullanılmasının Sayfa| 994 gerekliliği nedeniyle anket uygulama günlerinin hafta içi salı ile haftasonu cumartesi günleri arasında olmasına dikkat edilmiştir. Bununla birlikte sorular yöneltilirken bireylere bir gün önce sabah saat 6'dan bugün sabah 6'ya kadar yolculuk yapıp yapmadıkları sorularak, yolculuk yaptıklarını beyan etmeleri durumunda söz konusu yolculuklarına ilişkin seçilen ulaşım türü, durağa yürüme süresi, durakta bekleme süresi, varış noktasına yürüme süresi, parklanma süresi vb. bilgiler kayıt altına alınmıştır.

Bununla birlikte farklı yolculuk amaçlarıyla yerleşme içerisinde hareketlilikte bulunmak isteyen bireylerin yolculuğa çıkma konusundaki düşüncelerini/eğilimlerini etkileyebilecek maksimum değerler (maksimum yürüme süresi, maksimum yolculuk süresi, maksimum ödeme yapabilecekleri ücret vb.) Coğrafi Bilgi Sistemleri programı ile haritalandırılmıştır. Çalışma kapsamında anket uygulanan bireylerden alınan yanıtların haritalandırıması aşamasında alınan yanıtların ilçeler ve mahalleler bazında ortalamaları alınarak dakika ya da TL birimi üzerinden görselleştirilmiştir.

Dolayısıyla; ilçeler ve mahalleler bazında bireylerin (1) iş ve eğitim amaçlı yolculuklarında katlanabilecekleri maksimum ulaşım süreleri (dk), (2) alışveriş amaçlı yolculuklarında katlanabilecekleri maksimum ulaşım süreleri ( $\mathrm{dk})$, (3) otobüs, metro, banliyö ve tramvay için toplu taşıma 
duraklarına, minibüs ve dolmuşlar için toplu taşıma hatlarına ulaşımda katlanabilecekleri maksimum yürüme süreleri ( $\mathrm{dk}$ ), (4) otobüs, metro, banliyö ve tramvay için toplu taşıma duraklarında, minibüs ve dolmuşlar için toplu taşıma hatlarında katlanabilecekleri maksimum bekleme süreleri ( $\mathrm{dk}$ ), (5) özel araç kullanıcıları için katlanılabilir maksimum otopark ücretleri (TL) saptanarak, ortalamaları alınıp Coğrafi Bilgi Sistemleri programı aracılığıyla haritalandırılmıştır.

Sonraki aşamada sonuçlar literatürle ilişkilendirilerek değerlendirmelerde bulunulmuştur.

\section{ANALİZ SONUÇLARI}

Çalışma kapsamında güney batıdan kuzey batıya doğru İzmir'in merkez ilçeleri olan Güzelbahçe, Narlıdere, Balçova, Karabağlar, Konak, Gaziemir, Buca, Bornova, Bayraklı, Karşıyaka ve Çiğli'de toplam 400 adet hanehalkıyla (1200 kişi) yolculuk bilgilerini almaya yönelik ulaşım anketleri gerçekleştirilmiştir.

SPSS programı aracılığıyla gerçekleştirilen frekans analizleri sonucunda; 400 hanede toplam 1220 kişiye ulaşıldığı tespit edilmiştir. 400 hanede ulaşılan 1220 kişinin \%22,4'ü Bornova'da; \%14,9'u Buca'da; \%11,6'sı Konak'ta; \%11,3'ü ise Karabağlar'da yaşamaktadır (bkz. Tablo 1). Sayfa | 995

\begin{tabular}{|l|c|c|l|c|c|}
\hline İlçe Adı & Kişi Sayısı & Yüzde (\%) & İlçe Adı & Kişi Sayısı & Yüzde (\%) \\
\hline Balçova & 30 & 2,5 & Güzelbahçe & 61 & 5,0 \\
\hline Bayrakıı & 97 & 8,0 & Karabağlar & 138 & 11,3 \\
\hline Bornova & 273 & 22,4 & Karşıyaka & 52 & 4,3 \\
\hline Buca & 182 & 14,9 & Konak & 142 & 11,6 \\
\hline Çiğli & 93 & 7,6 & Narlıdere & 92 & 7,5 \\
\hline Gaziemir & 60 & 4,9 & & & \\
\hline
\end{tabular}

Tablo 1: Anket Çalışmaları Sonucu Ulaşılan 400 Hanede Yaşayan 1220 Kişinin İlçeler İtibariyle

Dağılımı

Balçova'da anket yapılan kişi sayısının 30; Karşıyaka, Gaziemir ve Güzelbahçe'de 31-58; Çiğli, Bayraklı ve Narlıdere'de 59-98; Konak, Buca ve Karabağlar'da 99-158 kişi aralığında olduğu; Bornova'nın ise 159-228 kişi ile anket yapılan hanelerde yaşayan toplam kişi sayısı itibariyle ilk sırada yer aldığı gözlenmiştir.

İzmir merkez ilçeler için işe okula ulaşım süresi eşiği 59 dakika; alışveriş noktasına ulaşım süresi için eşik süre 13 dakika; toplu taşıma durağına yürüme süresi için eşik süre 11 dakika; toplu taşıma durağında 
bekleme süresi için eşik süre 12 dakika; dolmuş hattına yürüme süresi için ise eşik süre 10 dakika olarak tespit edilmiştir. Otopark ücreti için ödenebilecek eşik miktar ise 8 TL olarak belirlenmiştir. Yolculuklar sırasında aktarma yapacak olmanın ise bireylerde yolculuğa başlamak için caydırıcı etkiye sahip olduğu belirlenmiştir.

İlçeler bazında incelenen ortalama değerler sonucunda işe ve okula ulaşım süreleri itibariyle Güzelbahçe ortalama $76 \mathrm{dk}$. ile ilk sırada yer almakta olup; Güzelbahçe'de yaşayanların 76 dk.'dan daha uzun ulaşım süresine sahip olmaları durumunda iş ya da okullarına daha yakın bir konuta taşınmayı düşünecekleri tespit edilmiştir. Güzelbahçe'yi Bayraklı (63 dk), Buca (61 dk), Çiğli (61 dk) ve Karşıyaka (60 dk) ilçelerinin izlediği belirlenmiş olup; en kısa ulaşım süresine sahip ilçenin ise 40 dakika ile Balçova olduğu belirlenmiştir.

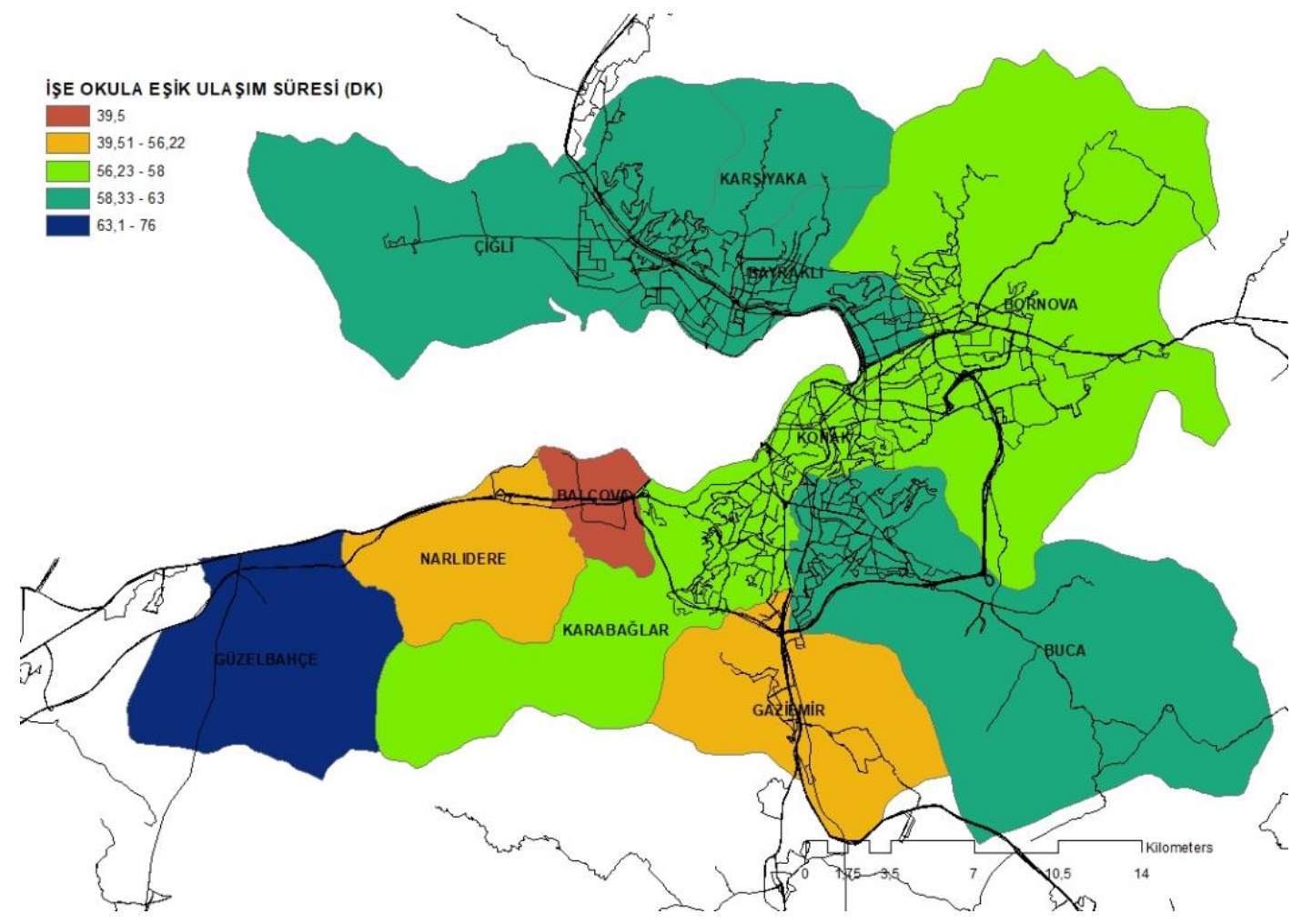

Şekil 1: İlçeler İtibariyle İş-Okul gibi Mecburi Yolculuklar için Eşik Ulaşım Süresi (dk)

Merkez, Valirahmibey ve Korutürk Mahalleleri işe-okula ulaşım süresi 36-45 dakikayı aşarsa daha yakın bir noktaya taşınmak isteyen mahallelerdir. Maltepe, İnönü, Gaziler, Dicle, Atatürk, Örnekköy, Kahramanlar, Kahramandere, Yalı, Yenigün ve Metin Oktay Mahalleleri ise 72-90 dakikada ulaşmaları durumunda daha yakın bir noktaya taşınmak isteyen mahallelerdir (bkz. Şekil 2). 


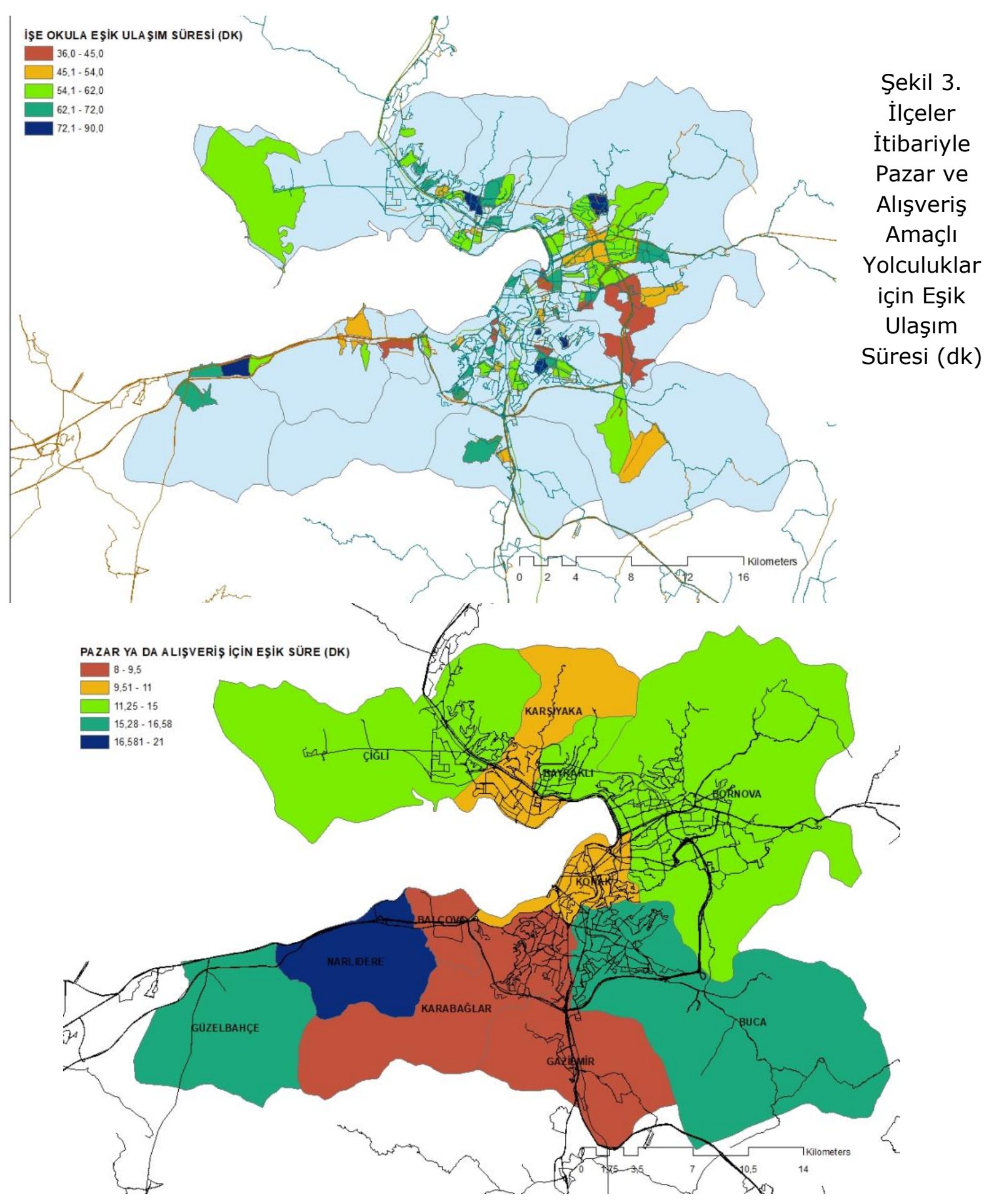

Şekil 2: Mahalleler İtibariyle İş-Okul gibi Mecburi Yolculuklar için Eşik Ulaşım Süresi (dk)

Alışveriş için eşik süreler ilçeler itibariyle incelendiğinde ise; ilk sırada özel araç sahipliliği yüksek olan Narlıdere (21 dk) yer almakta olup; Narlıdere'yi 17 dk ile Buca'nın, 16 dk. ile Güzelbahçe'nin izlediği tespit edilmiştir. Gaziemir ise 8 dakika ile en son sıradadır. Gaziemir'i 9 dk. ile Karabağlar ve $10 \mathrm{dk}$. ile Balçova izlemektedir (bkz. Şekil 3). 
Gökdere ve Yıldızlar mahalleleri alışveriş birimlerine 20 dakikalık sürede ulaşamamaları durumunda daha yakın bir noktaya taşınmak isteyen mahallelerdir. Atıfbey, Ferahlı, Adnan Süvari, Fahrettin Altay ve Metin Oktay Mahalleleri ise 6-7 dakikalık süreler ile en son sıradaki mahallelerdir (bkz. Şekil 4).

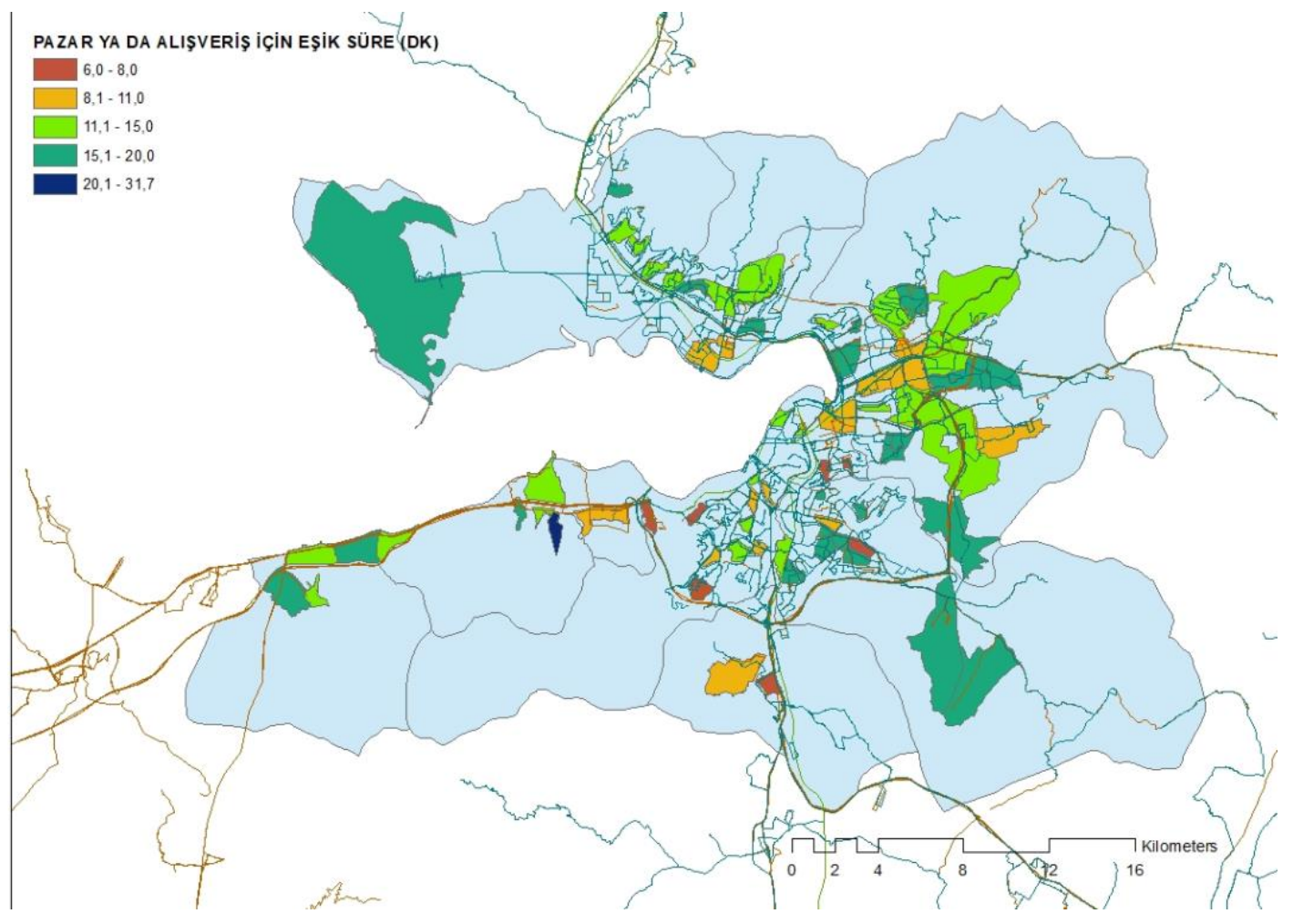

Sayfa | 998

Şekil 4: Mahalleler İtibariyle Pazar ve Alışveriş Amaçlı Yolculuklar için Eşik Ulaşım Süresi

Durağa yürüme süreleri itibariyle incelendiğinde ilk sırada Güzelbahçe (12 dk) ilçesi gelmekte olup; Balçova, Bayraklı, Buca, Çiğli ve Narlıdere'nin ise $11 \mathrm{dk}$. ile 2. sırada yeraldığı tespit edilmiştir. Gaziemir 8 dakika ile en düşük eşik değere sahip ilçedir (bkz. Şekil 5.). 
Şekil 5. İlçeler İtibariyle Toplu Taşıma Duraklarına Yürümek için Eşik Ulaşım Süresi (dk)

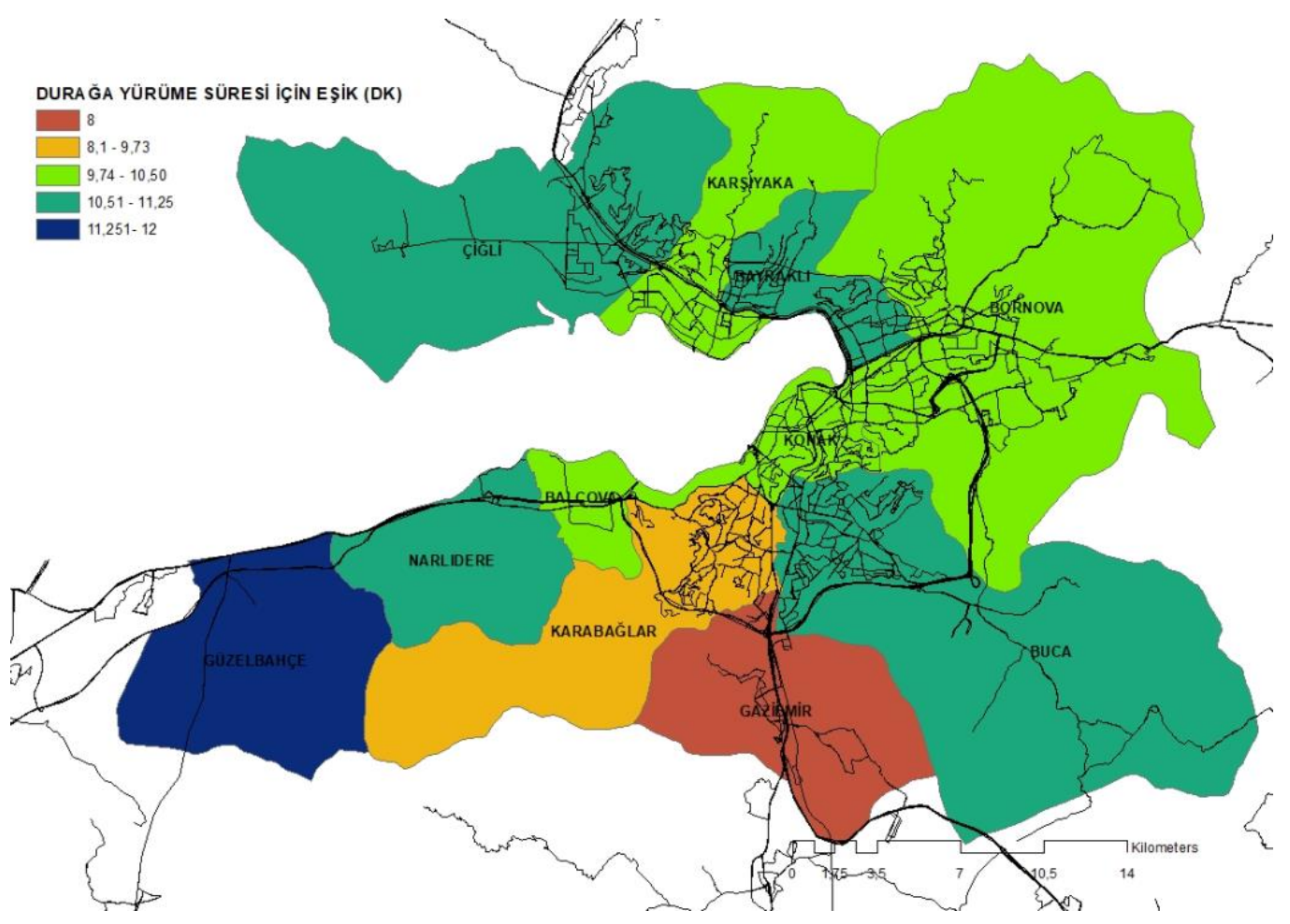

Sayfa | 999

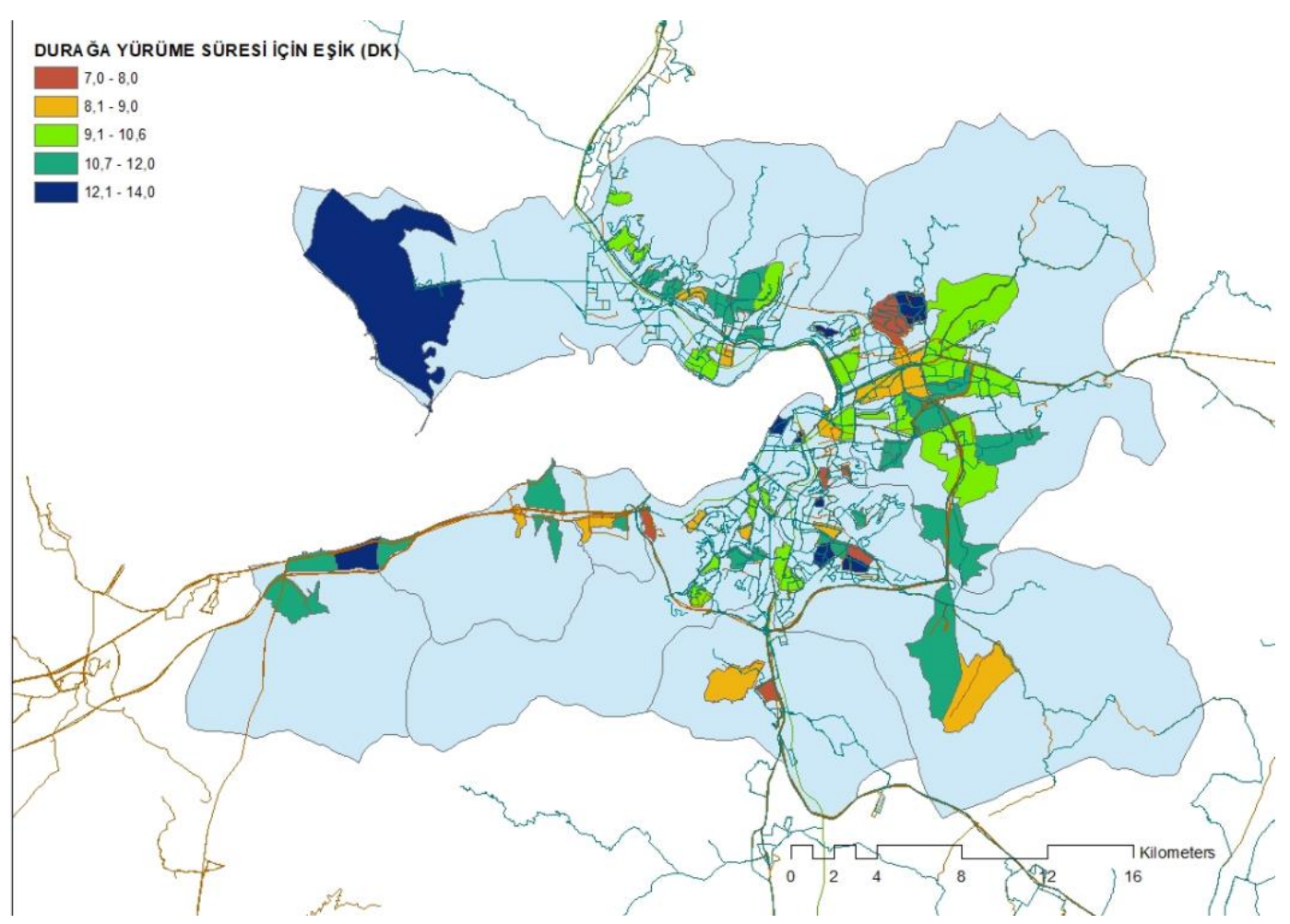

Şekil 6: Mahalleler İtibariyle Toplu Taşıma Duraklarına Yürümek için Eşik Ulaşım Süresi (dk) 
Yıldız, İnönü, Maltepe, Yenigün ve Tuzla Mahalleleri 14 dakikalık ulaşım süresi ile durağa yürüme süresi açısından ilk sırada yeralan mahallelerdir. Atıfbey, Saygı, Fahrettin Altay ve Atatürk Mahalleleri ise 8 dakika ile ön plana çıkmaktadır (bkz. Şekil 6).

Anket uygulanan bireylere durakta bekleme sürelerinde meydana gelecek artışın başka bir ulaşım türüne yönelimlerindeki etkisi de sorulan sorular arasındadır. Durakta bekleme süresi itibariyle Güzelbahçe (15 dk), Bayraklı (13 dk), Bornova, Buca ve Çiğli (12 dk) ilk sırada yeralan ilçeler olarak ön plana çıkmaktadır. Balçova ( $9 \mathrm{dk}$ ) ve Karabağlar (10 dk) ise diğer ilçelere göre daha düşük değerler tespit edilmiştir (bkz. Şekil 7).

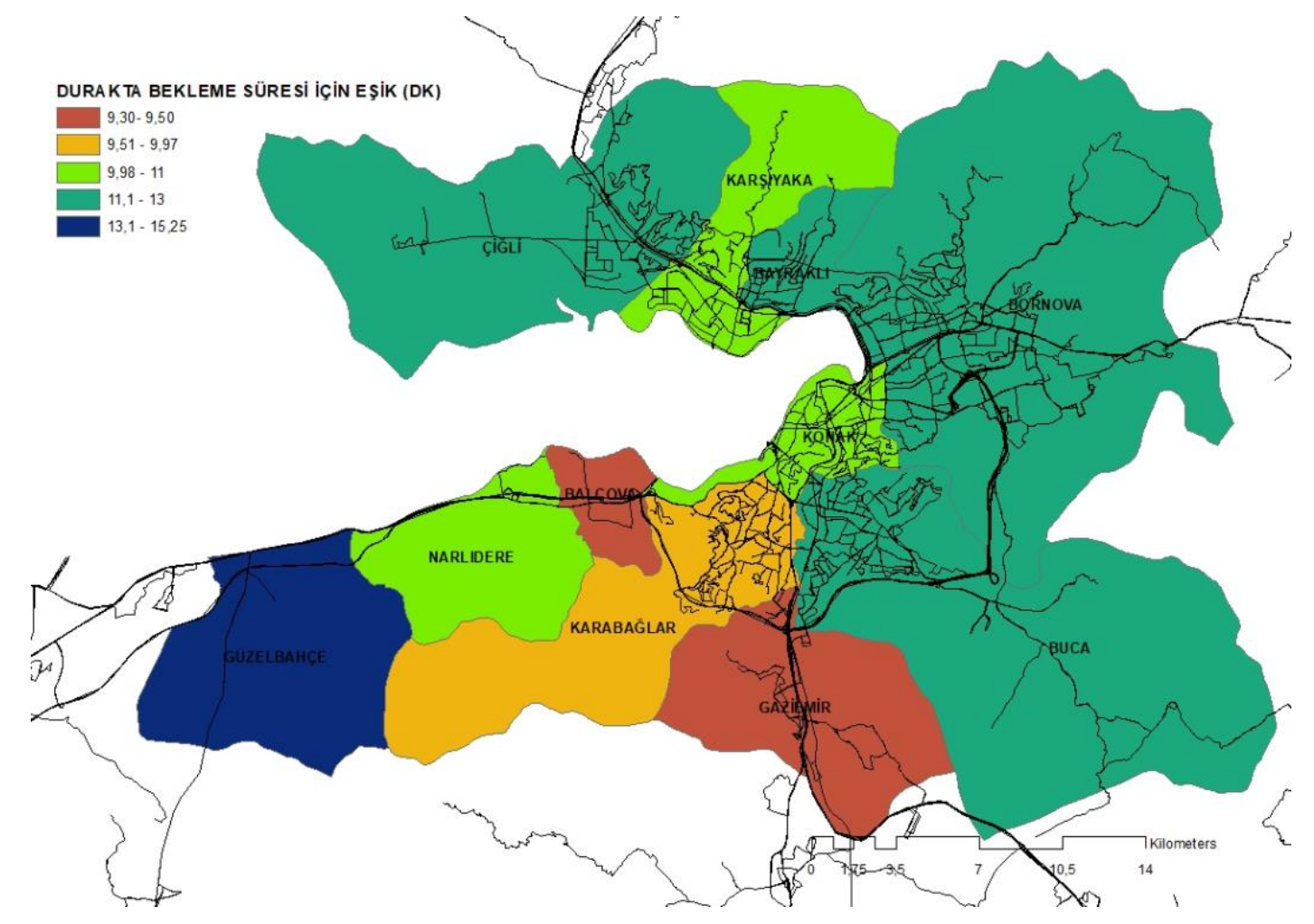

Sayfa | 1000

Şekil 7: İlçeler İtibariyle Toplu Taşıma Duraklarında Bekleme Süreleri için Eşik Ulaşım Süresi (dk)

Maltepe ve Tuzla 18 dakikalık durakta bekleme süreleri itibariyle ilk sırada yer alan mahalleler olup; Yıldız, Dicle ve Kahramandere mahalleleri ise 16 dakika ile 2. sırada yer almaktadır. Fahrettin Altay ve Zafertepe ise 7 dakikalık ortalama durakta bekleme süresine sahip mahallelerdir (bkz. Şekil 8). 


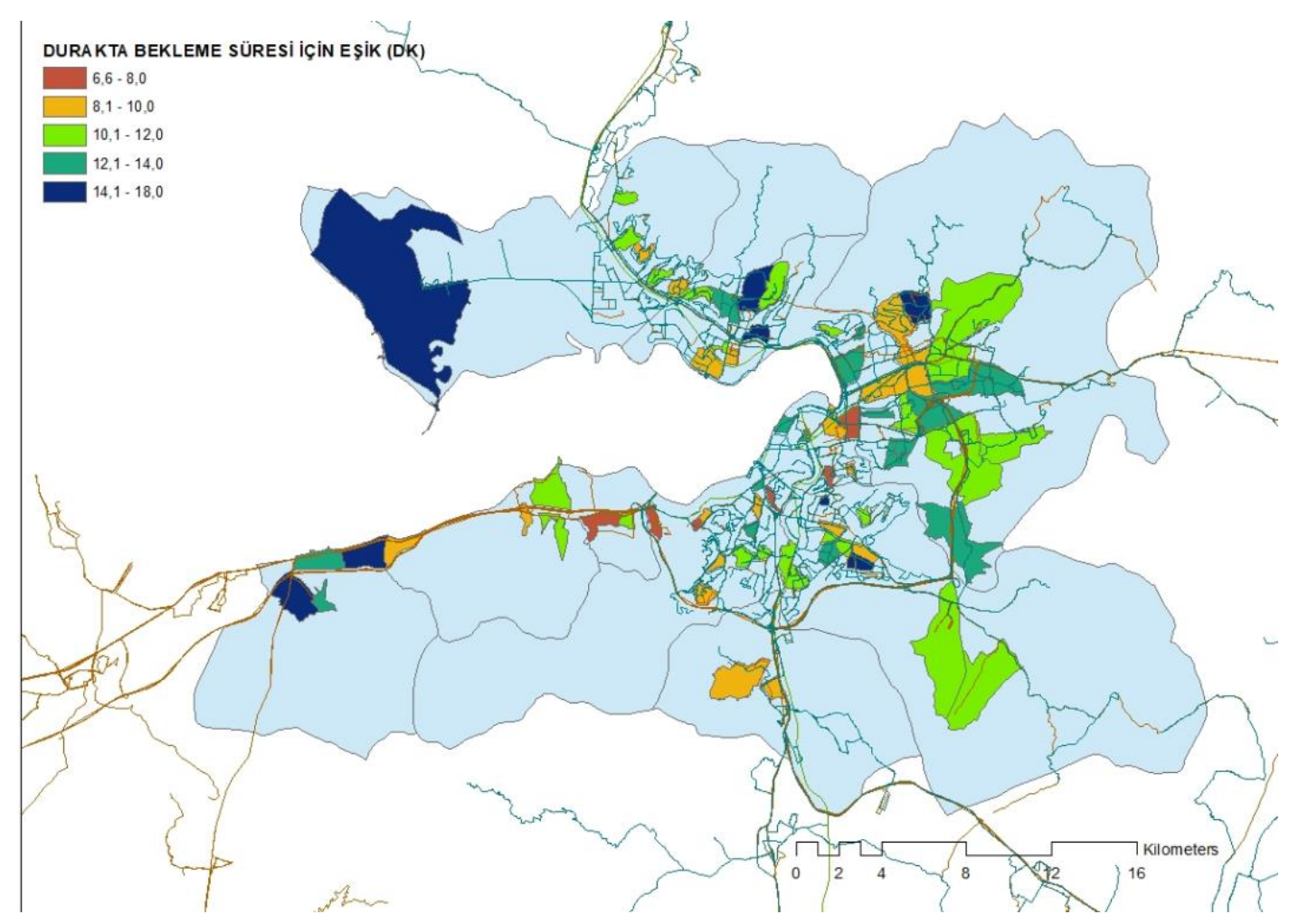

Şekil 8: İlçeler İtibariyle Toplu Taşıma Duraklarında Bekleme Süreleri için Eşik Ulaşım Süresi $\mathrm{dk}$ )

Dolmuş hattına yürüme süresi itibariyle Çiğli $12 \mathrm{dk}$. ile ilk sırada yer alırken; Güzelbahçe $11 \mathrm{dk}$. ile 2. sırada yer almaktadır. Balçova $8 \mathrm{dk}$. ile; Gaziemir, Karabağlar, Konak ve Narlıdere ise $9 \mathrm{dk}$. ile en düşük dolmuş hattına yürüme süresine sahip ilçelerdir (bkz. Şekil 9). 


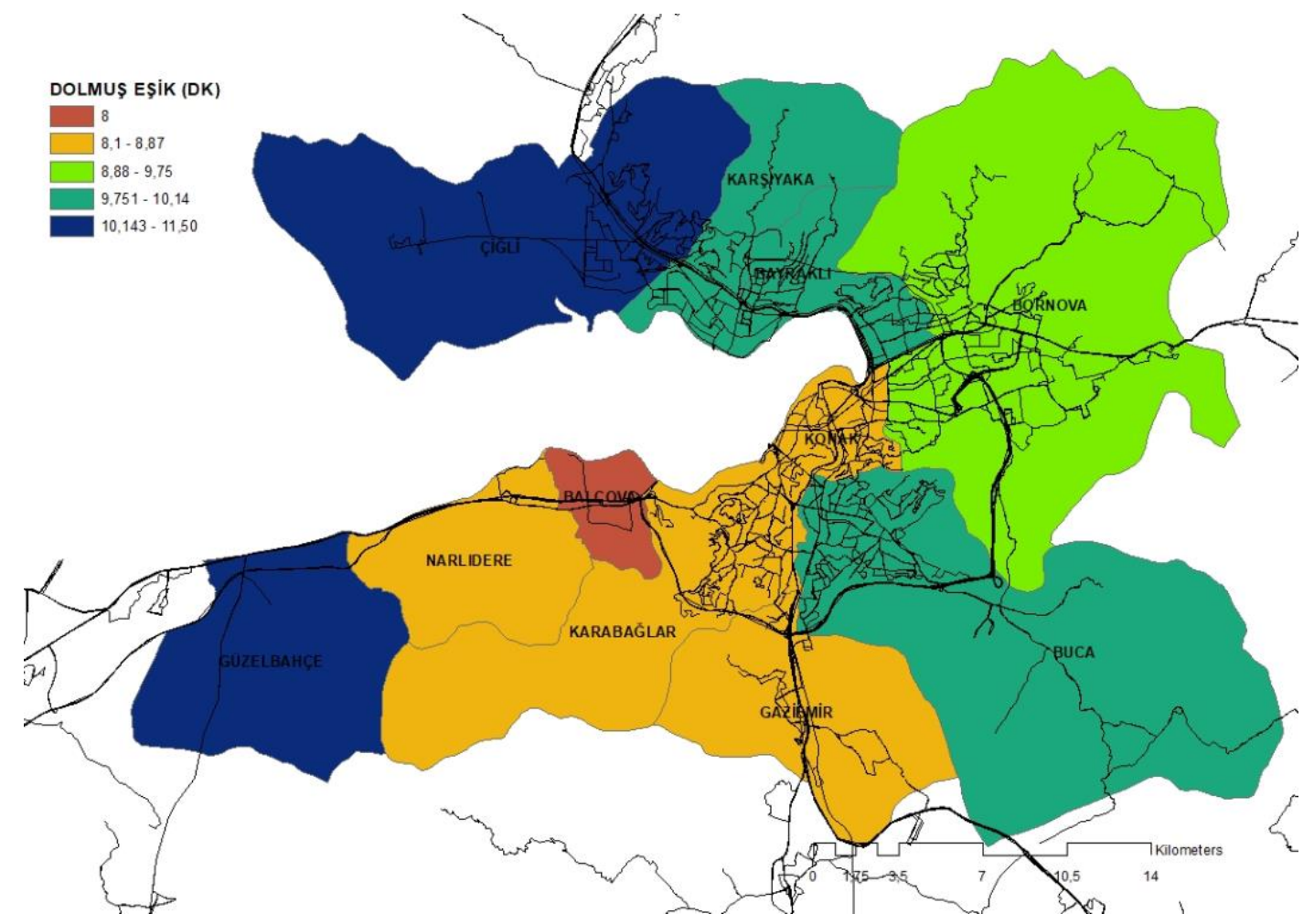

Şekil 9: İlçeler İtibariyle Dolmuşa Erişim Süreleri için Eşik Ulaşım Süresi (dk)

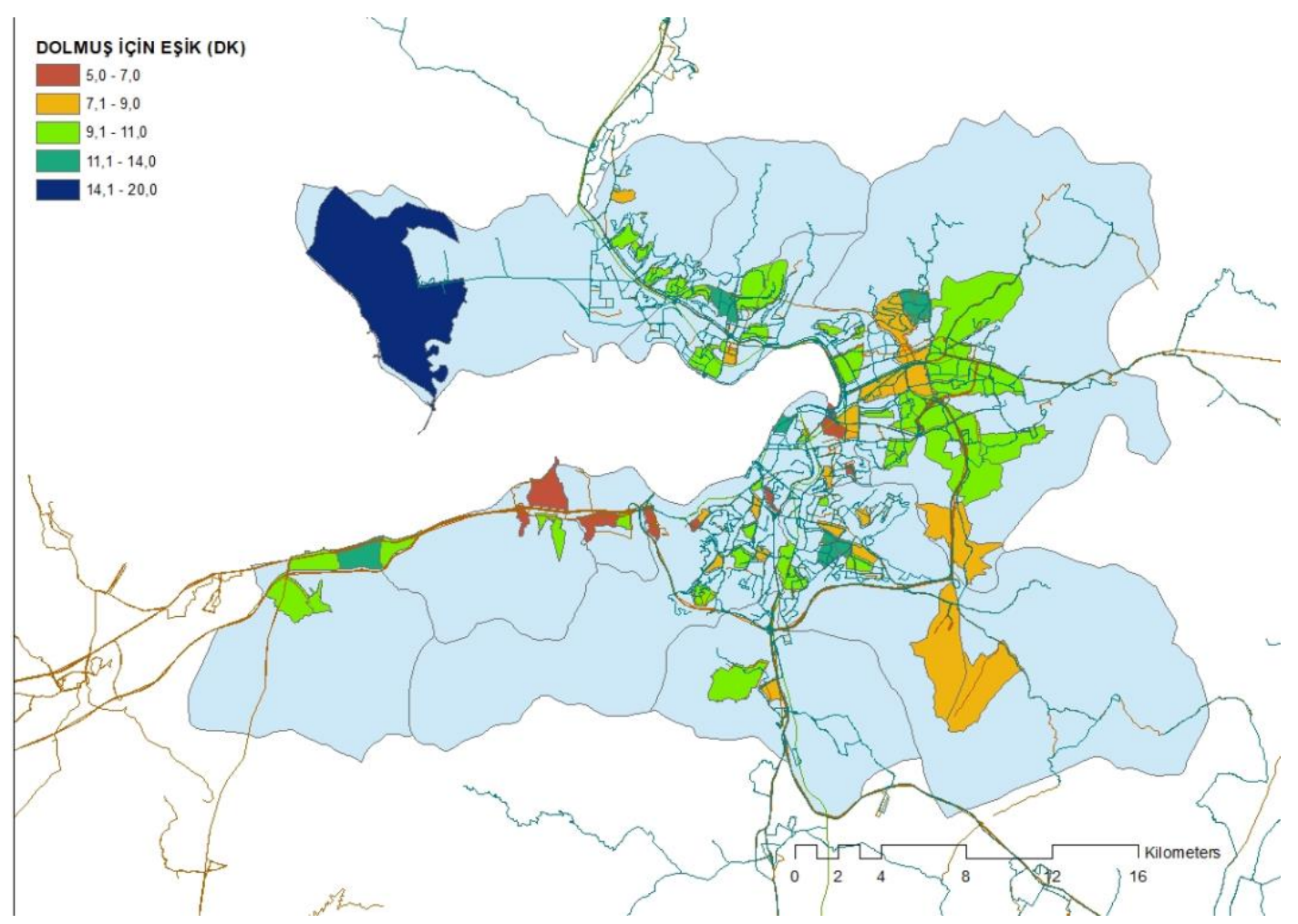

Şekil 10: Mahalleler İtibariyle Dolmuşa Erişim Süreleri için Eşik Ulaşım Süresi (dk) 
Dolmuş hattına yürüme süresi itibariyle Tuzla 20 dakika ile ilk sırada yeralırken; 14 dk. ile Yenigün mahallesi 2. sıradadır. Korutürk, Metin Oktay, Halkapınar ve Saygı mahalleleri ise 5-6 dakikalık ulaşım süreleri ile en düşük ortalama değere sahip mahalleler olarak ön plana çıkmaktadır (bkz. Şekil 10).

Otopark ücretinin kaç lira olması durumunda başka bir ulaşım alternatifi ararsınız sorusuna alınan yanıtlar ilçe bazında analiz edildiğinde; özel araç sahipliliği en yüksek olan Narlıdere ilçesi otopark ücretleri konusunda 16 TL ile özel aracını bırakıp toplu taşıma sistemine yönlenme konusunda en yüksek ortalama değere sahip ilçe olarak ön plana çıkmaktadır. 2. sırada 13 TL ile Güzelbahçe yer alırken; 3. sırada 10 TL ile Buca gelmektedir. Bayraklı ve Çiğli 3 TL ile otopark ücreti konusunda en düşük ortalamalara sahip ilçelerdir (bkz. Şekil 11).

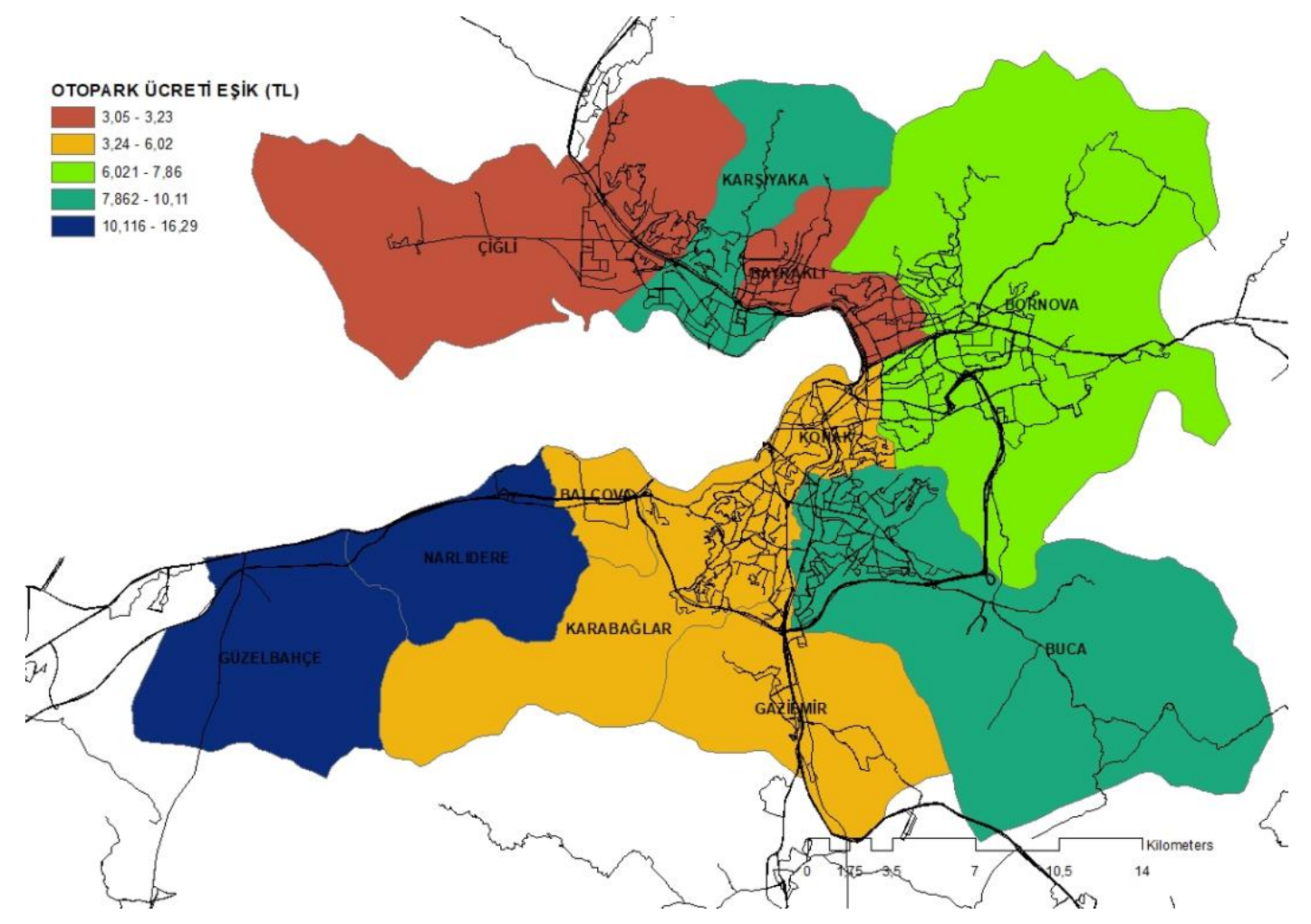

Sayfa | 1003

Şekil 11: İlçeler İtibariyle Parklanma için Ödenebilecek Eşik Değer (TL)

Yıldız, Sahilevleri, Zafer (Altındağ), Yalı, Atatürk, Limanreis, Valirahmibey, Çatalkaya ve Yenigün mahalleleri 16-20 TL'lik otopark ücretleri ile özel araçlarını bırakıp başka bir ulaşım türüne yönlenme konusunda en yüksek ortalamalara sahip mahalleler olarak ön plana çıkmaktadır. Alpaslan, Çaymahallesi, Esentepe, İnönü, Atıfbey, Onur, Ferahlı, Adnan Süvari, Saygı, Yurtoğlu, Umut, Kahramanlar, Fahrettin Altay, Irmak, Selvili, Zafer, Metinoktay, Halkapınar ve Gürpınar mahalleleri ise 2- 
5 TL'lik ücretlerle parklanma ücretine karşı en düşük eşik değere sahip mahalleler olarak ön plana çıkmaktadır (bkz. Şekil 12).

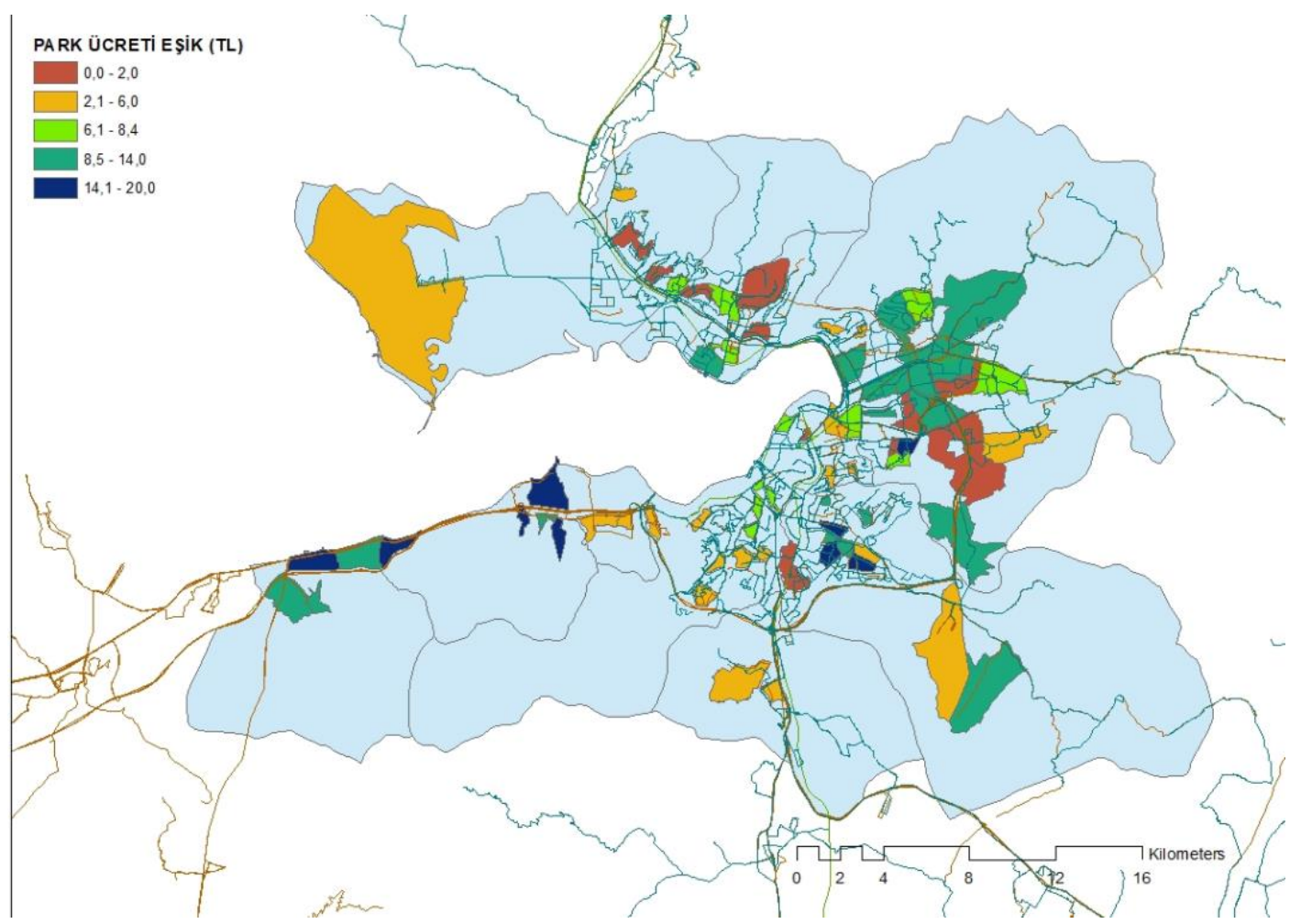

Şekil 12: Mahalleler İtibariyle Parklanma için Ödenebilecek Eşik Değer (TL)

Toplu taşıma türleri arasında aktarma yapıyor olmanın yolculuk tercihlerini nasıl değiştirdiği de anket sürecinde değerlendirilmeye çalışılmıştır. Bu kapsamda aktarma yapıyor olma konusunda 1. seçenek aktarma yapıyor olmanın başka bir ulaşım alternatifi aramasına neden olacağını; 2. seçenek aktarma yapıyor olmanın yolculuğu gerçekleştirmesinde caydırıcı etkiye sahip olacağını; 3 . seçenek ise aktarma yapıyor olmanın herhangi bir olumsuz etkisi olmadığını ifade etmektedir. Bireylerin bu seçenekler arasındaki tercihleri; değerlendirmeye tabi tutulmuştur. Analizler sonucunda; Narlıdere, Karşıyaka, Bayraklı ve Bornova ilçelerinin ortalaması; bu ilçelerde yaşayan bireylerin aktarma yapıyor olmasının başka bir ulaşım alternatifi aramasına neden olacağını göstermiştir. Çiğli, Balçova, Karabağlar, Konak, Buca, Güzelbahçe ve Gaziemir İlçeleri ise aktarma yapıyor olmanın yolculuğu gerçekleştirmede caydırıcı etkiye sahip olacağını ifade etmişlerdir. İlçeler arasında 3. seçenek olan aktarma yapıyor olmanın herhangi bir olumsuz etkisi olmadığını düşünen ilçe olmadığı; sonuç olarak aktarma yapmanın kademeli olarak bireylerin yolculuk tercihlerinde önemli bir etkisi olduğu tespit edilmiştir (bkz. Şekil 13). 


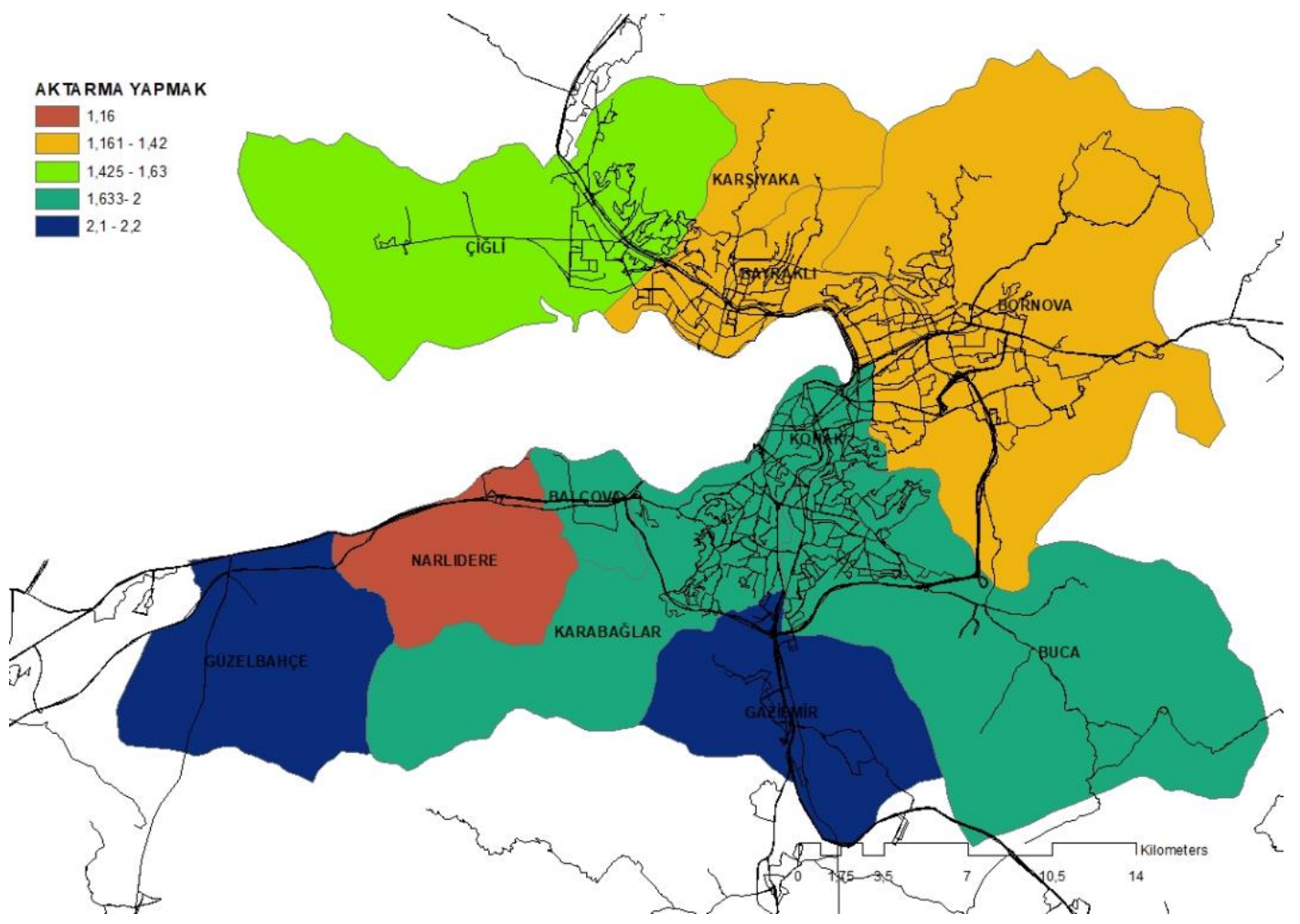

Şekil 13. İlçeler İtibariyle Aktarma Yapmak

Mersinli, Yenigün ve Atatürk mahalleleri aktarma yapıyor olmalarının Sayfa | 1005 yolculuk eğilimlerinde herhangi bir değişiklik oluşturmayacağını ifade eden mahalleler olarak belirlenmiştir (bkz. Şekil 14).

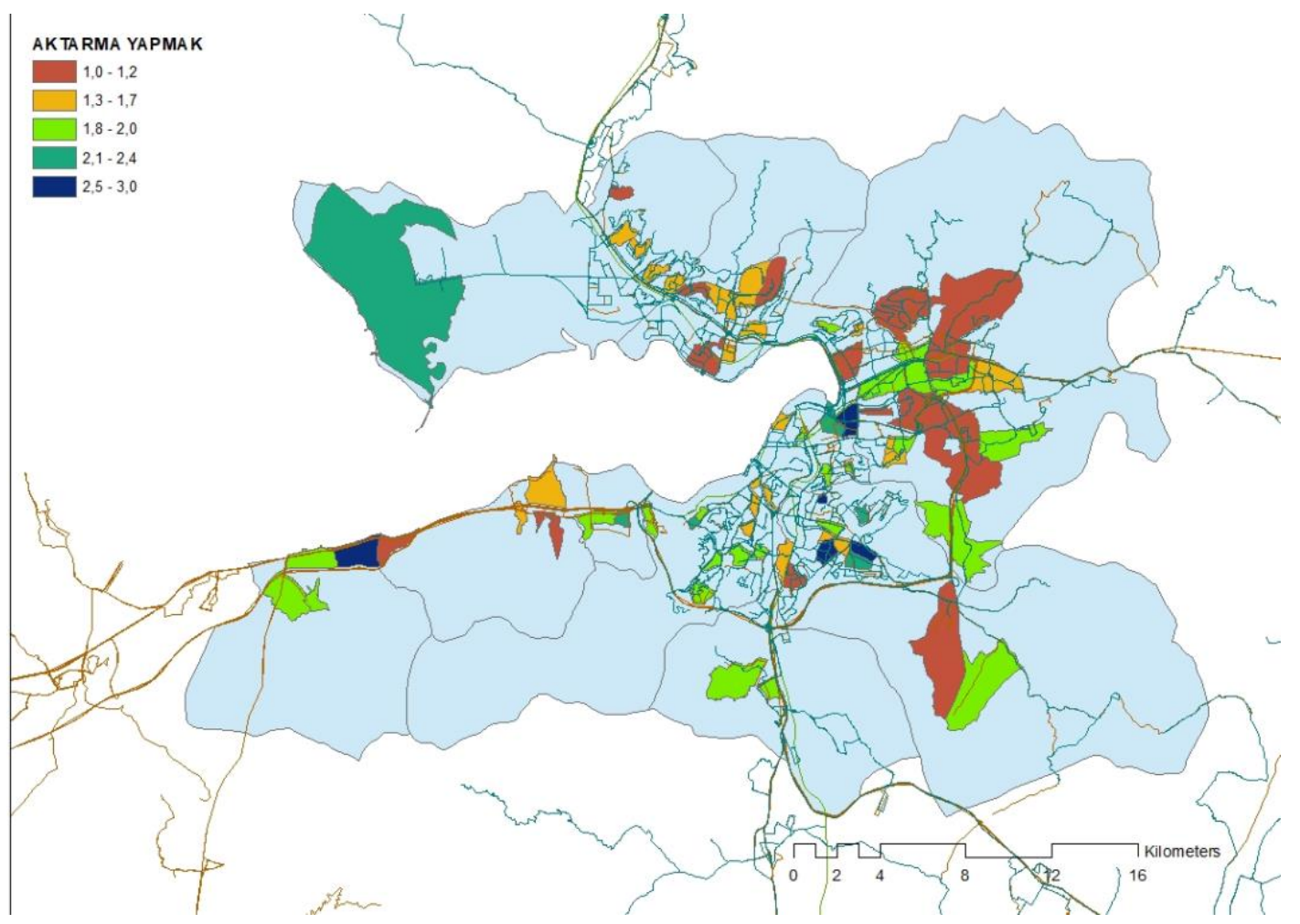

Şekil 14: Mahalleler İtibariyle Aktarma Yapmak 


\section{DEĞERLENDİRME VE SONUÇ}

Farklı özelliklere sahip yerleşmelerin; ulaşım sisteminin kullanıcısı olan bireylerin sahip olduğu sosyal, kültürel, demografik, ekonomik ve mekânsal özelliklere de bağlı olarak; ulaşım sisteminin özelliklerine dair verdiği tepkiler de farklılık göstermektedir.

Dolayısıyla, ulaşım sistemine yönelik kısa-orta-uzun vadeli politikalar ortaya koyulurken; yerleşme özelliklerine bağlı olarak ortaya çıkan eşik değerlerin dikkate alınması; farklı avantaj ya da dezavantaja sahip bireylere eşit hizmet götürülmesi açısından dikkate alınabilecek önemli bir kriterdir.

Ulaşım sistemine yönelik olarak geliştirilecek plan ve projelerde rehber niteliği taşıyabilecek bir veri olan ve bireylerin tercihlerini etkileyen eşik değerleri, İzmir merkez kent üzerinden ortaya koyuyor olması; bu çalışmanın bilime katkısını oluşturmaktadır.

Gelecek çalışmalarda; İzmir merkez ilçelerinin her birinde elde edilen eşik değerlerle, ilçelerin sahip olduğu özellikler arasındaki ilişkinin detaylı olarak analiz edilmesi ve plan hedef yılındaki nüfus büyüklüğüne ve yerleşmenin sahip olacağı diğer özelliklere bağlı olarak ulaşım ana planındaki politikaların ortaya koyulması; çıkan sonuçların anlamlandırılması açısından önemlidir.

Çalışma yerel/merkezi yönetimlerin ulaşım politikalarının belirlenmesinde ve mekânsal yer seçim kararlarının alınmasında ekonomik statüsü güçlü olanı avantajlı kılacak bir düzenleme yerine, alt ve orta sınıf için fırsat eşitliğini sağlamak amacıyla alınacak kararlara rehber niteliği taşıması açısından önemlidir. Çalışma Dokuz Eylül Üniversitesi Bilimsel Araştırma Projeleri Koordinasyon birimi tarafından desteklenen 2017.KB.FEN.016 numaralı projenin bir ürünüdür. Aynı zamanda Uluslararası Sosyal Bilimler ve Eğitim Bilimleri Kongresi (USVES) Ekim 2020'de sözlü bildiri olarak sunulmuş ve özet kitapçığında yayımlanmıştır.

\section{KAYNAKÇA}

Aile ve Sosyal Politikalar Bakanlığı. (2013). Erişilebilirlik İzleme ve Denetleme Yönetmeliği. Resmi gazete Sayı: 28713, 20.07.2013.

Cervero, R. (1995). Planned Communities, Self-containment and Commuting: A Cross-national Perspective. Urban Studies 32(7), 11351161.

Cojanu, V., Robert, D. \& Ileana, P-S. (2012). The Accessibility Buffer-A Basic GIS Tool in Determining the Competitive Potential Index. Procedia Environmental Sciences 14, 237-246. 
Ersoy, M. (2009). Kentsel Planlamada Arazi Kullanım Standartları. TMMOB Şehir Plancıları Odası. Ankara: BRC Basım ve Matbaacılık.

Martinelli, D. \& Medellin, L. (2007). Assessment of Bus Transit Equity in Two Metropolitan Areas, West Virginia University, Erişim Adresi: http://citeseerx.ist.psu.edu/viewdoc/download?doi=10.1.1.538.6291\&rep =rep $1 \&$ type $=p d f$

Ewing, R. \& R. Cervero. 2010. Travel and the Built Environment-A MetaAnalysis. Journal of the American Planning Association 76(3), 265-294. Geurs, K. T. \& Ritsema, J. R. van Eck, (2001). Accessibility Measures: Review and Applications, Evaluation of Accessibility Impacts of Land-Use Transport Scenarios, and Related Social and Economic Impacts. RIVM Report 408505 006, Erişim Adresi: 408505006accessibilitymeasures.pdf

Griffin, G. P. \& Sener, I. P. (2016). Public Transit Equity Analysis at Metropolitan and Local Scales: A Focus on Nine Large Cities in the US. Journal of Public Transportation 19(4), Erişim Adresi: http://scholarcommons.usf.edu/cgi/viewcontent.cgi?article=1575\&context =jpt

Henderson, W. \& Blackwell, A. G., (2015). How Better Transportation Can Fight Income Inequality. Erişim Adresi: http://thehill.com/blogs/congress- Sayfa | 1007 blog/economy-budget/244832-how-better-transportation-can-fightincome-inequality E.T.02.02.2017

Lemans, A. C. D. (2015). Assessing the Accessibility and Equity of the Urban Public Transport Services. (Master's Thesis). Erişim Adresi: http://repository.tudelft.nl/assets/uuid: d69faad6-4db5-4241-8633-

2515a8be04bd/Master_Thesis_Niek_Lemans_FINAL_pdf.pdf

Peng, Z. (1997). The Jobs-Housing Balance and Urban Commuting. Urban Studies 34(8), 1215-1235.

Ramsey, K. \& A. Bell. (2014). Access to Jobs and Workers via Transit. Washington, DC: U.S. EPA Office of Sustainable Communities. Erişim Adresi: https://edg.epa.gov/data/Public/OP/ SLD/SLD_Trans45_UG.pdf.

Mortazavi, S. A. H. \& Akbarzadeh, M. (2017). A Framework for Measuring the Spatial Equity in the Distribution of Public Transportation Benefits. Journal of Public Transportation 20(1), Erişim Adresi: http://scholarcommons.usf.edu/cgi/viewcontent.cgi?article=1589\&context =jpt

Nawagawong, W. \& Techapeeraparnich, W. (2017). Providing Facilities to Improve Accessibilities to Railway Station for All, MATEC Web of Conferences 138, 07013 EACEF 2017, 10.1051/matecconf/201713807013, 
https://www.matec-

conferences.org/articles/matecconf/pdf/2017/52/matecconf eacef2017 0 7013.pdf

T.C. Cumhurbaşkanlığı Mevzuat Bilgi Sistemi. (2020). Mekansal Planlar Yapım Yönetmeliği. Resmi Gazete Sayı: 29030, 14.06.2014.

Türk Dil Kurumu Sözlükleri (TDK). (2020). https://sozluk.gov.tr/

GENIŞ̧LETímiş̧ ÖZET: Ulaşım bizi sadece işe ve ekonomik fırsatlara değil; kaliteli konuta, okula, sağık bakımına ulaştıran bir role sahiptir. Harvardlı araştırmacılar yolculuk süresinin sosyal hareketlilik çıtasını yükseltmede önemli bir kestirim aracı olduğunu tespit etmişlerdir (Henderson ve Blackwell, 2015). Adil ulaşım politikaları; ekonomik hareketlilikle baş etme şansına sahiptir ve toplumdaki herkesin yerel ekonomiye katıımını ve yerel ekonomiden faydalanmasını garanti ederler (Henderson ve Blackwell; 2015). Farklı özelliklere sahip yerleşmelerin; ulaşım sisteminin kullanıcısı olan bireylerin sahip olduğu sosyal, kültürel, demografik, ekonomik ve mekânsal özelliklere de bağlı olarak; ulaşım sisteminin özelliklerine dair verdiği tepkiler de farklıık göstermektedir. Dolayısıyla, ulaşım sistemine yönelik kısa-orta-uzun vadeli politikalar ortaya koyulurken; yerleşme özelliklerine bağı olarak ortaya çıkan eşik değerlerin dikkate alınması; farklı avantaj ya da dezavantaja sahip bireylere eşit hizmet götürülmesi açısından dikkate alınabilecek önemli bir kriterdir. Literatürde ulaşımın adil dağıımını analiz etmeye yönelik olarak pek çok çalışma bulunmakta olup; ulaşımın adil dağılımı Sayfa | 1008 konusunda toplu taşıma sisteminin önemi; söz konusu çalışmalarla ortaya koyulmaktadır. Bu kapsamda Griffin ve Şener (2016), Martinelli ve Medellin (2007), Teunissen, Sarmiento, Zuidgeest ve Brussel (2015), Nawagawong ve Techapeeraparnich (2017), Cojanua, Dobreb ve Stupariuc (2012), Mortazavi ve Akbarzadeh'ın (2017) ve Guzmana ve Bocarejob'un (2017) çalışmaları incelenmiştir. Bu çalışmanın amacı; mekansal planlama ya da ulaşım sistemlerinin planlanması ya da söz konusu alanlarda politika geliştirilmesinde bir araç olarak kullanılabilecek; kentin kullanıcılarının yer seçim ya da ulaşıma yönelik eğilimlerini değiştirme etkisine sahip eşik erişilebilirlik değerleri konusuna dikkat çekmek ve bu değerleri İzmir merkez kent üzerinden analiz etmektir. Bu çalışmada "eşik değer" kavramıyla gün içerisinde farklı yolculuk amaçlarıyla yerleşme içerisinde hareketlilikte bulunmak isteyen bireylerin yolculuğa çıkma konusundaki düşüncelerini/eğilimlerini etkileyebilecek maksimum değerleri (maksimum yürüme süresi, maksimum yolculuk süresi, maksimum ödeme yapabilecekleri ücret vb.) ortaya koymak amaçlanmakta olup; çalışma kapsamında anket uygulanan bireylerden alınan yanıtların ilçeler ve mahalleler bazında ortalamaları alınarak dakika ya da TL birimi üzerinden aktarımlar gerçekleştirilmeye çalışılmıştır. Çalışmada kullanılan bilimsel yöntemler (1) İzmir merkez kentte yaşayanların yolculuk eğilimlerini ortaya koyması nedeniyle araştırmanın amaçları itibariyle "durum saptayıcı", (2) uygulanan anketlerde örneklem birimlerinin hafta içine denk gelen ve bir gün önceki sabah 6'dan bugün sabah 6'ya kadar olan 24 saatlik seyahat zincirlerini ortaya koyuyor olması nedeniyle kapsadığı zaman itibariyle 
"kesitsel", (3) uygulanan anket çalışması nedeniyle veri toplama biçimi itibariyle "anket yöntemini kullanan", (4) literatür araştırmaları itibariyle veri toplama biçimi açısından bakıldığında "kitaplık ve internet araştırmalarına" dayanan, (5) İzmir Merkez Kentte gerçekleştirilen anket çalışmalarına dayanıyor olması nedeniyle yapıldığı yer itibariyle "saha araştırmalarına dayanan" bir yönteme sahiptir. Çalışma İzmir Merkez Kentte yer alan otoyol, viyadük ve altgeçitler hariç; toplam 8456 sokaktan; rastlantısal olarak belirlenen 101 sokakta gerçekleştirilen 400 hane halkı anketini kapsamaktadır. Anket süreci gerçekleştirilirken bireylerin herhangi bir zamandaki değil bir gün önceki yolculuk bilgilerinin alınarak ulaşım talep modelleme sürecinde kullanılmasının gerekliliği nedeniyle anket uygulama günlerinin hafta içi salı ile haftasonu cumartesi günleri arasında olmasına dikkat edilmiştir. Bununla birlikte sorular yöneltilirken bireylere bir gün önce sabah saat 6'dan bugün sabah 6'ya kadar yolculuk yapıp yapmadıkları sorularak, yolculuk yaptıklarını beyan etmeleri durumunda söz konusu yolculuklarına ilişkin seçilen ulaşım türü, durağa yürüme süresi, durakta bekleme süresi, varış noktasına yürüme süresi, parklanma süresi vb. bilgiler kayıt altına alınmıştır. Bununla birlikte farklı yolculuk amaçlarıyla yerleşme içerisinde hareketlilikte bulunmak isteyen bireylerin yolculuğa çıkma konusundaki düşüncelerini/eğilimlerini etkileyebilecek maksimum değerler (maksimum yürüme süresi, maksimum yolculuk süresi, maksimum ödeme yapabilecekleri ücret vb.) Coğrafi Bilgi Sistemleri programı ile haritalandırılmıştır. Çalışma kapsamında anket uygulanan bireylerden alınan yanıtların haritalandırıması aşamasında alınan yanıtların ilçeler ve mahalleler Sayfa | 1009 bazında ortalamaları alınarak dakika ya da TL birimi üzerinden görselleştirilmiştir. Dolayısıyla; ilçeler ve mahalleler bazında bireylerin (1) iş ve eğitim amaçlı yolculuklarında katlanabilecekleri maksimum ulaşım süreleri (dk), (2) alışveriş amaçlı yolculuklarında katlanabilecekleri maksimum ulaşım süreleri (dk), (3) otobüs, metro, banliyö ve tramvay için toplu taşıma duraklarına, minibüs ve dolmuşlar için toplu taşıma hatlarına ulaşımda katlanabilecekleri maksimum yürüme süreleri (dk), (4) otobüs, metro, banliyö ve tramvay için toplu taşıma duraklarında, minibüs ve dolmuşlar için toplu taşıma hatlarında katlanabilecekleri maksimum bekleme süreleri ( $\mathrm{dk}$ ), (5) özel araç kullanıcıları için katlanılabilir maksimum otopark ücretleri (TL) saptanarak, ortalamaları alınıp Coğrafi Bilgi Sistemleri programı aracılığıyla haritalandırılmıştır. Çalışma yerel/merkezi yönetimlerin (1) kent içi ulaşım politikalarının belirlenmesinde ve (2) mekânsal planlar yapım yönetmeliğindeki yürünebilirlik esaslarının tartışılmasında dolayısıyla mekânsal yerseçim kararlarının gözden geçirilmesinde katkı sağlayacaktır. Çalışma Dokuz Eylül Üniversitesi Rektörlüğü Bilimsel Araştırmalar Koordinasyon Birimi tarafından desteklenen 2017.KB.FEN.016 No'lu projenin bir ürünüdür. Aynı zamanda Uluslararası Sosyal Bilimler ve Eğitim Bilimleri Kongresi (USVES) Ekim 2020'de sözlü bildiri olarak sunulmuştur.

EXTENDED ABSTRACT: Transportation drives us not only to employment and economic opportunities; It has a role in providing quality housing, school and health care. Harvard researchers found that travel time is an important predictor of raising the bar for social mobility (Henderson and Blackwell, 2015). Fair 
transport policies; have a chance to cope with economic mobility and ensure that everyone in the community participates and benefits from the local economy (Henderson and Blackwell; 2015). Settlements with different characteristics; depending on the social, cultural, demographic, economic and spatial characteristics of the individuals who are the users of the transportation system; responses to the characteristics of the transportation system also differ. Therefore, while establishing short-medium-long-term policies for the transportation system; taking into account the threshold values that occur depending on the settlement characteristics; is an important criterion that can be taken into account in terms of providing equal service to individuals with different advantages or disadvantages. There are many studies in the literature to analyze the fair distribution of transportation. The importance of the public transport system in the fair distribution of transport; demonstrated by these studies. In this context, Griffin and Şener (2016), Martinelli and Medellin (2007), Teunissen, Sarmiento, Zuidgeest and Brussel (2015), Nawagawong and Techapeeraparnich (2017), Cojanua, Dobreb and Stupariuc (2012), Mortazavi and Akbarzadeh (2017) and Guzmana and Bocarejob (2017) were reviewed. The aim of this study is to draw attention to the issue of threshold accessibility values that can be used as a tool in spatial planning, planning of transportation systems or policy development in these areas and that have the effect of changing the location selection or transportation tendencies of the city users, and to analyze these values over the central city of Izmir. In this study, with the concept of "threshold value", it is aimed Sayfa | 1010 to reveal the maximum values (maximum walking time, maximum travel time, maximum payment, etc.) that can affect the thoughts / tendencies of individuals who want to be mobile in the settlement for different travel purposes during the day; Within the scope of the study, the average of the answers received from the individuals who were surveyed on the basis of districts and neighborhoods was tried to be transferred in minutes or TL units. The scientific methods used in the study are (1) "status detector", since it reveals the travel tendencies of the people living in the central city of Izmir, for the purposes of the research; (2) "crosssectional" in terms of the time they cover, since the sample units in the applied questionnaires reveal the 24-hour travel chains from 6 a.m. the previous day to 6 a.m. today, (3) "using the survey method" in terms of data collection due to the survey study applied, (4) based on "library and internet research" in terms of data collection in terms of literature researches, (5) "based on field research" in terms of the place where it was conducted. Study includes 400 household surveys conducted on 101 randomly determined streets, from a total of 8456 streets, excluding highways, viaducts and underpasses in İzmir Central City. During the survey process, attention was paid to keep the survey application days between Tuesdays on weekdays and Saturdays on weekends, since it is necessary to use the travel information of individuals not at any time, but the day before, in the transportation demand modeling process. However, when asking questions, individuals were asked whether they had traveled from 6 a.m. to 6 a.m. the day before, and if they declared that they had traveled, the type of transportation chosen for their journey, walking time to the station, waiting time at the stop, 
walking time to the destination, parking time etc. information has been recorded. In addition, the maximum values (maximum walking time, maximum travel time, maximum payment, etc.) that can affect the thoughts / tendencies of individuals who want to be mobile in the settlement for different travel purposes have been mapped with the Geographical Information Systems program. During the mapping phase of the responses received from the individuals surveyed within the scope of the study, the averages of the responses received on the basis of districts and neighborhoods were visualized in minutes or TL units. Therefore; on the basis of districts and neighborhoods, (1) maximum travel times ( $\mathrm{min}$ ) that individuals can endure on their business and educational journeys, (2) maximum transportation times $(\mathrm{min})$ they can endure on their shopping journeys, (3) public transportation stops for buses, subways, suburbs and trams, Maximum walking time (min) for minibuses and minibuses they can endure in transportation to public transport lines, (4) maximum waiting times ( $\mathrm{min}$ ) that they can endure at public transport stops for buses, subways, suburbs and trams, and public transport lines for minibuses and minibuses, (5) special Maximum bearable parking fees (TL) for vehicle users were determined, averaged, and mapped through the Geographical Information Systems program. The study will contribute to (1) determining the urban transportation policies of the local/central governments and (2) discussing the walkability principles in the spatial plans construction regulation, thus reviewing the spatial location decisions. The study is a product of the project numbered 2017.KB.FEN.016 supported by Dokuz Eylül University Rectorate Sayfa | 1011 Scientific Research Coordination Unit. At the same time, the International Social Sciences and Educational Sciences Congress (USVES) was presented as an oral presentation in October 2020. 